Conduct of Operations Applicability Matrix for CMELS Low Hazard Facilities at LLNL Site 200

G. A. Cooper

April 25, 2008 
This document was prepared as an account of work sponsored by an agency of the United States government. Neither the United States government nor Lawrence Livermore National Security, LLC, nor any of their employees makes any warranty, expressed or implied, or assumes any legal liability or responsibility for the accuracy, completeness, or usefulness of any information, apparatus, product, or process disclosed, or represents that its use would not infringe privately owned rights. Reference herein to any specific commercial product, process, or service by trade name, trademark, manufacturer, or otherwise does not necessarily constitute or imply its endorsement, recommendation, or favoring by the United States government or Lawrence Livermore National Security, LLC. The views and opinions of authors expressed herein do not necessarily state or reflect those of the United States government or Lawrence Livermore National Security, LLC, and shall not be used for advertising or product endorsement purposes.

This work performed under the auspices of the U.S. Department of Energy by Lawrence Livermore National Laboratory under Contract DE-AC52-07NA27344. 


\title{
Appendix C Conduct of Operations Applicability Matrix \\ Conduct of Operations Applicability Matrix for CMELS Low Hazard Facilities at LLNL Site 200
}

\section{April 2008}

\author{
LLNL-TR-403181 \\ Building 132N, Area A \\ Building 151 \\ Building 152 \\ Building 154 \\ Building 190 \\ Building 235 \\ Building 364
}

DISCLAIMER

\begin{abstract}
This document was prepared as an account of work sponsored by an agency of the United States government. Neither the United States government nor Lawrence Livermore National Security, LLC, nor any of their employees makes any warranty, expressed or implied, or assumes any legal liability or responsibility for the accuracy, completeness, or usefulness of any information, apparatus, product, or process disclosed, or represents that its use would not infringe privately owned rights. Reference herein to any specific commercial product, process, or service by trade name, trademark, manufacturer, or otherwise does not necessarily constitute or imply its endorsement, recommendation, or favoring by the United States government or Lawrence Livermore National Security, LLC. The views and opinions of authors expressed herein do not necessarily state or reflect those of the United States government or Lawrence Livermore National Security, LLC, and shall not be used for advertising or product endorsement purposes.
\end{abstract}

This work performed under the auspices of the U.S. Department of Energy by Lawrence Livermore National Laboratory under Contract DE-AC52-07NA27344. 


\section{Conduct of Operations Applicability Matrix}

This Matrix applies to the following facilities:

Building 132N, Area A, Building 151, Building 152, Building 154, Building 190, Building 235 Building 364

Matrix table based on the LLNL Environment Safety \& Health Manual Document 3.5, Conduct of Operations for LLNL Facilities

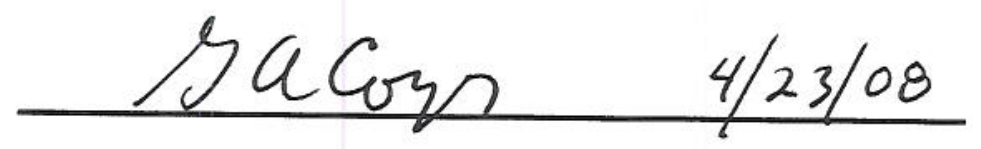

Prepared by Greg Cooper, AD Facility Manager, CMELS

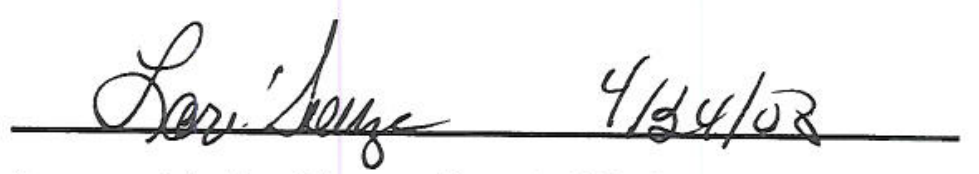

Approved by Lori Souza, Deputy AD, Operations, CMELS

NNSA/LSO Approval

This document has been reviewed and verified not to contain classified information.

ADC'ed by Laura Gilliom on April 23, 2008. 


\section{Conduct of Operations Applicability Matrix for Low Hazard Facilities}

The following table documents applicability of the Conduct of Operations elements per ES\&H Manual Document 3.5, Conduct of Operations for LLNL Facilities, to operations in LLNL facilities. Applicable implementing documents, processes, and programs are listed.

\begin{tabular}{|c|c|c|c|c|}
\hline $\begin{array}{l}\text { ES\&H MANUAL } \\
\text { DOCUMENT } 3.5 \\
\text { SECTION }\end{array}$ & $\begin{array}{l}\text { REQUISITES FOR SECTION } \\
\text { ELEMENTS }\end{array}$ & $\begin{array}{l}\text { APPLICABLE } \\
\text { YES/NO }\end{array}$ & $\begin{array}{l}\text { RESPONSIBILITY } \\
\text { FOR } \\
\text { COMPLIANCE } \\
\text { FMC/PMC }^{1}\end{array}$ & $\begin{array}{l}\text { COMMENTS AND/OR REFERENCE FOR } \\
\text { VERIFICATION OF COMPLIANCE }\end{array}$ \\
\hline \multicolumn{5}{|l|}{$\begin{array}{l}\text { OPERATIONS } \\
\text { ORGANIZATION } \\
\text { ADMINISTRATION } \\
\text { SECTION } 1.0\end{array}$} \\
\hline $\begin{array}{l}\text { 1.2.1. Operations } \\
\text { Policies }\end{array}$ & $\begin{array}{l}\text { a) Operating policies and procedures } \\
\text { should be defined (e.g., FSPs, } \\
\text { IWS, IWS/SPs, Work Procedures, } \\
\text { Standard Operating Procedures } \\
\text { [SOPs]) including responsibilities } \\
\text { for implementation. }\end{array}$ & Yes & FMC/PMC & $\begin{array}{l}\text { LLNL ES\&H Manual Documents } 2.1 \& 2.2 \\
\text { CMELS-330, ISMS Implementation Plan } \\
\text { CMLS-410, FSP for CMS Complexes } \\
\text { FSP B190 } \\
\text { CMLS-411, FSP } 360 \text { Complex } \\
\text { CMLS-412, FSP } 360 \text { Complex, Biohazardous } \\
\text { Operations }\end{array}$ \\
\hline \multirow[t]{2}{*}{ 1.2.2. Resources } & $\begin{array}{l}\text { a) A long-range staffing plan that } \\
\text { anticipates personnel losses } \\
\text { should be developed and } \\
\text { implemented for key positions that } \\
\text { require special training/ } \\
\text { qualification, certificates and/or } \\
\text { licenses. }\end{array}$ & No & NA & $\begin{array}{l}\text { There are no Key Positions identified for which } \\
\text { special training/qualification, certificate and/or } \\
\text { licenses are required. }\end{array}$ \\
\hline & $\begin{array}{l}\text { b) Staffing levels should comply with } \\
\text { the level of ES\&H support } \\
\text { specified in resource planning } \\
\text { documents. }\end{array}$ & Yes & FMC/PMC & $\begin{array}{l}\text { CMELS-330 and ES\&H Manual Document } 2.1 \\
\text { defines the role of the Authorizing Organization } \\
\text { to allocate sufficient resources to ensure safe, } \\
\text { efficient, and compliant operations. } \\
\text { CMELS-330 defines the roles of the CMELS } \\
\text { DAD/Ops to oversee and manage operations. } \\
\text { The AD Resource Manager ensures ES\&H } \\
\text { needs are incorporated into budgets and } \\
\text { resource planning. }\end{array}$ \\
\hline
\end{tabular}

\footnotetext{
${ }^{1}$ Facility Management Chain/Program Management Chain
} 


\section{Conduct of Operations Applicability Matrix for Low Hazard Facilities}

\begin{tabular}{|c|c|c|c|c|}
\hline $\begin{array}{l}\text { ES\&H MANUAL } \\
\text { DOCUMENT } 3.5 \\
\text { SECTION }\end{array}$ & $\begin{array}{l}\text { REQUISITES FOR SECTION } \\
\text { ELEMENTS }\end{array}$ & $\begin{array}{l}\text { APPLICABLE } \\
\text { YES/NO }\end{array}$ & $\begin{array}{c}\text { RESPONSIBILITY } \\
\text { FOR } \\
\text { COMPLIANCE } \\
\text { FMC/PMC }\end{array}$ & $\begin{array}{l}\text { COMMENTS AND/OR REFERENCE FOR } \\
\text { VERIFICATION OF COMPLIANCE }\end{array}$ \\
\hline & $\begin{array}{l}\text { Define organizational } \\
\text { responsibilities for both } \\
\text { programmatic and support } \\
\text { organization personnel. }\end{array}$ & Yes & $\mathrm{FMC/PMC}$ & $\begin{array}{l}\text { CMELS-330 (Integrated Safety Management } \\
\text { System [ISMSI) and ES\&H Manual Document } \\
2.1 \text { (General Worker Responsibilities and } \\
\text { Integrated Safety Management) describes } \\
\text { organizational responsibilities for programmatic } \\
\text { and support organizations. } \\
\text { This and all CMELS documents cited in this } \\
\text { worksheet can be found at the following URL: } \\
\text { http://sodium.IInl.gov/cmels/?url=library- } \\
\text { policies and procedures } \\
\text { CMELS Organization Chart - AD Office } \\
\text { http://sodium.IInl.gov/cmls/?url=library- } \\
\text { organizations } \\
\text { AEED Organization Chart } \\
\text { http://sodium.IInl.gov/cmls/data/assets/images/o } \\
\text { rg/aeed/aeed orgcht.gif } \\
\text { BBTD Organization Chart } \\
\text { http://sodium.IInl.gov/cmls/data/assets/images/o } \\
\text { rg/bbtd/bbtd orgcht.gif } \\
\text { CBD Organization Chart } \\
\text { http://sodium.IInl.gov/cmls/data/assets/images/o } \\
\text { rg/csd/csd orgcht.gif } \\
\text { MSTD Organization Chart } \\
\text { http://sodium.IInl.gov/cmls/data/assets/images/o } \\
\text { rg/mstd/mstd orgcht.gif }\end{array}$ \\
\hline
\end{tabular}




\section{Conduct of Operations Applicability Matrix for Low Hazard Facilities}

\begin{tabular}{|c|c|c|c|c|}
\hline $\begin{array}{c}\text { ES\&H MANUAL } \\
\text { DOCUMENT } 3.5 \\
\text { SECTION } \\
\end{array}$ & $\begin{array}{c}\text { REQUISITES FOR SECTION } \\
\text { ELEMENTS }\end{array}$ & $\begin{array}{c}\text { APPLICABLE } \\
\text { YES/NO }\end{array}$ & $\begin{array}{c}\text { RESPONSIBILITY } \\
\text { FOR } \\
\text { COMPLIANCE } \\
\text { FMC/PMC }^{1} \\
\end{array}$ & $\begin{array}{l}\text { COMMENTS AND/OR REFERENCE FOR } \\
\text { VERIFICATION OF COMPLIANCE }\end{array}$ \\
\hline & $\begin{array}{l}\text { d) Identify the individual responsible } \\
\text { for implementing the ES\&H } \\
\text { controls in the FSP or IWS/SP. }\end{array}$ & Yes & FMC & $\begin{array}{l}\text { CMELS-330 and ES\&H Manual Document } 2.1 \\
\text { defines roles, responsibilities, and authorities. } \\
\text { Responsibilities by role are also defined in } \\
\text { CMELS Facility Safety Plans (FSPs). For } \\
\text { IWS/SPs (formerly OSPs), the responsible } \\
\text { individuals are specifically named. }\end{array}$ \\
\hline \multirow[t]{3}{*}{$\begin{array}{l}\text { 1.2.3. Monitoring of } \\
\text { Operating } \\
\text { Performance }\end{array}$} & $\begin{array}{l}\text { a) Operating and safety goals should } \\
\text { be established. }\end{array}$ & Yes & $\mathrm{FMC/PMC}$ & $\begin{array}{l}\text { CMELS- } 330 \text { establishes commitments and } \\
\text { metrics for meeting LLNL safety goals, } \\
\text { performance measures, and the success of the } \\
\text { ISMS. CMELS-330 assigns responsibility to the } \\
\text { Authorizing Organization to define technical } \\
\text { objectives of the work activity. Programmatic } \\
\text { goals are defined by each program (in each } \\
\text { Work request) and also in a broad sense in } \\
\text { "LLNL Technical Strategic Plan for High } \\
\text { Explosives Technology," (UCRL-ID-128722, } \\
\text { Dec. 1997). }\end{array}$ \\
\hline & $\begin{array}{l}\text { b) Work supervisors or their } \\
\text { designees should regularly } \\
\text { observe important operational } \\
\text { activities to identify and correct } \\
\text { safety and operating deficiencies. }\end{array}$ & Yes & FMC/PMC & $\begin{array}{l}\text { CMELS-330 defines provisions for } \\
\text { reviewing/analyzing safety data within the } \\
\text { Directorate. CMLS-305 defines provisions for } \\
\text { rolling up data to the Institutional level for } \\
\text { trending. } \\
\text { ES\&H Manual, Document 2.1, General Worker } \\
\text { Responsibilities and Integrated Safety } \\
\text { Management. }\end{array}$ \\
\hline & $\begin{array}{l}\text { c) Document and evaluate operating } \\
\text { problems and develop corrective } \\
\text { actions to improve performance. }\end{array}$ & Yes & $\mathrm{FMC} / \mathrm{PMC}$ & $\begin{array}{l}\text { CMLS-305 (ES\&H Self-Assessment Plan) } \\
\text { specifies schedules and requirements for self- } \\
\text { assessments. CMELS senior management, } \\
\text { Division management, and Work Supervisors } \\
\text { routinely observe operations in walk-arounds. }\end{array}$ \\
\hline
\end{tabular}




\section{Conduct of Operations Applicability Matrix for Low Hazard Facilities}

\begin{tabular}{|c|c|c|c|c|}
\hline $\begin{array}{l}\text { ES\&H MANUAL } \\
\text { DOCUMENT } 3.5 \\
\quad \text { SECTION }\end{array}$ & $\begin{array}{l}\text { REQUISITES FOR SECTION } \\
\text { ELEMENTS }\end{array}$ & $\begin{array}{l}\text { APPLICABLE } \\
\text { YES/NO }\end{array}$ & $\begin{array}{c}\text { RESPONSIBILITY } \\
\text { FOR } \\
\text { COMPLIANCE } \\
\text { FMC/PMC }^{1} \\
\end{array}$ & $\begin{array}{l}\text { COMMENTS AND/OR REFERENCE FOR } \\
\text { VERIFICATION OF COMPLIANCE }\end{array}$ \\
\hline \multirow[t]{2}{*}{ 1.2.4. Accountability } & $\begin{array}{l}\text { a) Written performance appraisals } \\
\text { should provide feedback to } \\
\text { workers about their safety and job } \\
\text { performance. }\end{array}$ & Yes & FMC/PMC & $\begin{array}{l}\text { CMELS-330 establishes requirements to } \\
\text { ensure safety accountability is part of the } \\
\text { performance appraisal process. CMELS-104 } \\
\text { (Performance Appraisal, Ranking, and Salary } \\
\text { Policy) requires that the Performance Appraisal } \\
\text { include information on ES\&H responsibilities } \\
\text { and expectations, and that employees be } \\
\text { appraised on the performance of those } \\
\text { responsibilities. }\end{array}$ \\
\hline & $\begin{array}{l}\text { b) Formal performance appraisals } \\
\text { should be provided at least } \\
\text { annually and should document } \\
\text { operational performance. }\end{array}$ & Yes & FMC/PMC & $\begin{array}{l}\text { CMELS-330 establishes requirements to } \\
\text { ensure safety accountability is part of the } \\
\text { performance appraisal process. CMELS-104 } \\
\text { (Performance Appraisal, Ranking, and Salary } \\
\text { Policy) requires that the Performance Appraisal } \\
\text { include information on ES\&H responsibilities } \\
\text { and expectations, and that employees be } \\
\text { appraised on the performance of those } \\
\text { responsibilities. }\end{array}$ \\
\hline
\end{tabular}




\section{Conduct of Operations Applicability Matrix for Low Hazard Facilities}

\begin{tabular}{|c|c|c|c|c|}
\hline $\begin{array}{l}\text { ES\&H MANUAL } \\
\text { DOCUMENT } 3.5 \\
\quad \text { SECTION }\end{array}$ & $\begin{array}{l}\text { REQUISITES FOR SECTION } \\
\text { ELEMENTS }\end{array}$ & $\begin{array}{l}\text { APPLICABLE } \\
\text { YES/NO }\end{array}$ & $\begin{array}{l}\text { RESPONSIBILITY } \\
\text { FOR } \\
\text { COMPLIANCE } \\
\text { FMC/PMC }^{1}\end{array}$ & $\begin{array}{l}\text { COMMENTS AND/OR REFERENCE FOR } \\
\text { VERIFICATION OF COMPLIANCE }\end{array}$ \\
\hline $\begin{array}{l}\text { 1.2.5. Management } \\
\text { Training }\end{array}$ & $\begin{array}{l}\text { a) Managers (NF/HHF/MHF) and } \\
\text { work supervisors (ALL) should } \\
\text { receive training in supervisory } \\
\text { skills, ES\&H issues specific to the } \\
\text { facility, and facility operations in } \\
\text { their area of responsibility. }\end{array}$ & Yes & $\mathrm{FMC/PMC}$ & $\begin{array}{l}\text { CMELS-330 \& ES\&H Manual Document } 2.1 \\
\text { establish Authorizing Organization/Individual } \\
\text { responsibilities to include designating an } \\
\text { appropriate RI and to provide support to that RI } \\
\text { and to ensure that individuals conducting the } \\
\text { work possess the necessary skills, knowledge, } \\
\text { and abilities (SKA). } \\
\text { CMELS-330 assigns training responsibilities to } \\
\text { the CMELS DAD/Ops to manage the CMELS } \\
\text { Training Program and assigns responsibilities } \\
\text { to Payroll Supervisors to develop personnel } \\
\text { skills to ensure necessary SKAs. The Payroll } \\
\text { Supervisors also ensure accuracy of the } \\
\text { LTRAIN Questionnaire to develop LTRAIN } \\
\text { profiles to identify Institutional and } \\
\text { Organizational Training Requirements for } \\
\text { managers and supervisors, and use LTRAIN to } \\
\text { track completion of those courses. }\end{array}$ \\
\hline $\begin{array}{l}\text { 1.2.6. Planning for } \\
\text { Safety }\end{array}$ & $\begin{array}{l}\text { a) Safety preplanning and review } \\
\text { process for routine work and new } \\
\text { processes or experiments should } \\
\text { be documented. }\end{array}$ & Yes & $\mathrm{FMC} / \mathrm{PMC}$ & $\begin{array}{l}\text { CMELS-330 and ES\&H Manual Document } 2.1 \\
\text { establishes the Integration Work Sheet (IWS) } \\
\text { process to review new work activities not } \\
\text { commonly performed by the public and to set } \\
\text { requirements to ensure operations are within } \\
\text { the safety basis envelope of each facility. }\end{array}$ \\
\hline \multicolumn{5}{|l|}{$\begin{array}{l}\text { SHIFT ROUTINES } \\
\text { AND OPERATING } \\
\text { PRACTICES } \\
\text { SECTION } 2.0 \\
\end{array}$} \\
\hline $\begin{array}{l}\text { 2.2.1. Status } \\
\text { Practices }\end{array}$ & $\begin{array}{l}\text { a) Responsible operators/workers } \\
\text { should be promptly notified of } \\
\text { changes in equipment or system } \\
\text { status. }\end{array}$ & Yes & $\mathrm{FMC/PMC}$ & $\begin{array}{l}\text { CMELS S200 LHF facilities do not utilize } \\
\text { multiple shifts. Equipment or systems for which } \\
\text { prompt notification of status change is required } \\
\text { are identified in FSPs and IWSs. The methods } \\
\text { of notification are defined in these documents. }\end{array}$ \\
\hline
\end{tabular}




\section{Conduct of Operations Applicability Matrix for Low Hazard Facilities}

\begin{tabular}{|c|c|c|c|c|c|}
\hline $\begin{array}{l}\text { ES\&H MANUAL } \\
\text { DOCUMENT } 3.5 \\
\text { SECTION }\end{array}$ & & $\begin{array}{c}\text { REQUISITES FOR SECTION } \\
\text { ELEMENTS }\end{array}$ & $\begin{array}{l}\text { APPLICABLE } \\
\text { YES/NO }\end{array}$ & $\begin{array}{c}\text { RESPONSIBILITY } \\
\text { FOR } \\
\text { COMPLIANCE } \\
\text { FMC/PMC }^{1}\end{array}$ & $\begin{array}{l}\text { COMMENTS AND/OR REFERENCE FOR } \\
\text { VERIFICATION OF COMPLIANCE }\end{array}$ \\
\hline & b) & $\begin{array}{l}\text { Operators/workers should be } \\
\text { instructed to promptly notify the } \\
\text { facility and/or program } \\
\text { management chain (as } \\
\text { appropriate) of abnormalities; } \\
\text { abnormal, unusual or emergency } \\
\text { events; changes in operational } \\
\text { status; significant changes in } \\
\text { schedules; and difficulties } \\
\text { encountered in performing tasks. }\end{array}$ & Yes & FMC/PMC & $\begin{array}{l}\text { CMELS-330 defines the occurrence reporting } \\
\text { process for CMELS. FSPs also refer to the } \\
\text { processes defined in CMELS-330. } \\
\text { CMELS-330 discusses CMELS emergency } \\
\text { response plans and processes. FSPs also } \\
\text { contain information on how to respond to } \\
\text { emergencies. } \\
\text { CMLS-409 (CMELS Site } 200 \text { Employee } \\
\text { Emergency Response Self-Help Guide) (hard } \\
\text { copies of this document are available in all } \\
\text { laboratories and offices) also provides guidance } \\
\text { to employees on reporting unexpected events } \\
\text { and unknowns. }\end{array}$ \\
\hline 2.2.2.Safety Practices & & Develop safety plans. & Yes & FMC/PMC & $\begin{array}{l}\text { CMELS-330 and ES\&H Manual Document 3.3, } \\
\text { "Facility Safety Plans and Integration Work } \\
\text { Sheets with Safety Plans," implement the } \\
\text { requirements to prepare FSPs and IWS/SPs. } \\
\text { The FSPs for CMELS facilities also provide } \\
\text { guidance for when IWS/SPs are required. } \\
\text { ES\&H Manual, Document 2.2, Managing ES\&H } \\
\text { for LLNL Work. }\end{array}$ \\
\hline
\end{tabular}




\section{Conduct of Operations Applicability Matrix for Low Hazard Facilities}

\begin{tabular}{|c|c|c|c|c|c|}
\hline \multirow[t]{4}{*}{$\begin{array}{l}\text { ES\&H MANUAL } \\
\text { DOCUMENT } 3.5 \\
\text { SECTION }\end{array}$} & & $\begin{array}{c}\text { REQUISITES FOR SECTION } \\
\text { ELEMENTS }\end{array}$ & $\begin{array}{l}\text { APPLICABLE } \\
\text { YES/NO }\end{array}$ & $\begin{array}{c}\text { RESPONSIBILITY } \\
\text { FOR } \\
\text { COMPLIANCE } \\
\text { FMC/PMC }^{1}\end{array}$ & $\begin{array}{l}\text { COMMENTS AND/OR REFERENCE FOR } \\
\text { VERIFICATION OF COMPLIANCE }\end{array}$ \\
\hline & & $\begin{array}{l}\text { Workers are trained to properly } \\
\text { operate equipment and } \\
\text { understand the safety plans. }\end{array}$ & Yes & $\mathrm{FMC} / \mathrm{PMC}$ & $\begin{array}{l}\text { CMELS-330 and ES\&H Manual Document } 2.1 \\
\text { directs the RI to ensure worker qualifications } \\
\text { including an understanding of the FSP and } \\
\text { IWS/SP. } \\
\text { CMELS FSPs describe appropriate responses } \\
\text { to facility emergencies. Facility management } \\
\text { provides FSP briefings to Site } 200 \text { facility } \\
\text { residents via CH2202-W (FSP Training: CMS } \\
\text { Laboratories \& Facilities) and BR2201 (Facility } \\
\text { Safety Plan Training for Biological Facilities) and } \\
\text { documents this in LTRAIN. FSP190 addresses } \\
\text { training appropriate for workers, this includes } \\
\text { OJT, and job specific training. } \\
\text { Formal training is documented and verified } \\
\text { through LTRAIN. }\end{array}$ \\
\hline & & $\begin{array}{l}\text { Adhere to requirements in the } \\
\text { Industrial safety program. }\end{array}$ & Yes & FMC/PMC & $\begin{array}{l}\text { The Industrial Safety (IS) Program is } \\
\text { documented in the IS Discipline Action Plans } \\
\text { (DAP) maintained by ES\&H Teams } 2 \text { (Site } \\
\text { 200), which captures the requirements of the } \\
\text { ES\&H Manual. }\end{array}$ \\
\hline & d) & $\begin{array}{l}\text { Adhere to requirements in the } \\
\text { Health physics program. }\end{array}$ & Yes & $\mathrm{FMC/PMC}$ & $\begin{array}{l}\text { The Health Physics (HP) Program is } \\
\text { documented in the HP DAP maintained by } \\
\text { ES\&H Teams } 2 \text { (Site 200), which captures the } \\
\text { requirements of the ES\&H Manual. } \\
\text { ES\&H Manual, Document 20.1, Occupational } \\
\text { Radiation Protection. }\end{array}$ \\
\hline & & $\begin{array}{l}\text { Adhere to requirements in the } \\
\text { Industrial hygiene program. }\end{array}$ & Yes & FMC/PMC & $\begin{array}{l}\text { The Industrial Hygiene (IH) Program is } \\
\text { documented in the IH DAP maintained by } \\
\text { ES\&H Teams } 2 \text { (Site 200), which captures the } \\
\text { requirements of the ES\&H Manual. } \\
\text { ES\&H Manual, Documents } 11.1,11.2,12.2 \text {, } \\
13.1 \text {, and } 14.1 \text {. }\end{array}$ \\
\hline
\end{tabular}




\section{Conduct of Operations Applicability Matrix for Low Hazard Facilities}

\begin{tabular}{|c|c|c|c|c|c|}
\hline \multirow[t]{3}{*}{$\begin{array}{l}\text { ES\&H MANUAL } \\
\text { DOCUMENT } 3.5 \\
\text { SECTION }\end{array}$} & & $\begin{array}{l}\text { REQUISITES FOR SECTION } \\
\text { ELEMENTS }\end{array}$ & $\begin{array}{l}\text { APPLICABLE } \\
\text { YES/NO }\end{array}$ & $\begin{array}{c}\text { RESPONSIBILITY } \\
\text { FOR } \\
\text { COMPLIANCE } \\
\text { FMC/PMC }^{1} \\
\end{array}$ & $\begin{array}{l}\text { COMMENTS AND/OR REFERENCE FOR } \\
\text { VERIFICATION OF COMPLIANCE }\end{array}$ \\
\hline & f) & $\begin{array}{l}\text { Adhere to requirements in the } \\
\text { Criticality safety program. }\end{array}$ & Yes & $\mathrm{FMC} / \mathrm{PMC}$ & $\begin{array}{l}\text { The Criticality Safety Program is documented } \\
\text { in the Criticality DAP maintained by ES\&H } \\
\text { Team 2, which captures the requirements of } \\
\text { the ES\&H Manual. In addition, the Criticality } \\
\text { Safety Section of the Hazards Control } \\
\text { Department reviews activities involving the } \\
\text { potential for nuclear criticality at the request the } \\
\text { Health Physicist or Facility Management. } \\
\text { ES\&H Manual, Document 20.6, Criticality } \\
\text { Safety. }\end{array}$ \\
\hline & & $\begin{array}{l}\text { Adhere to requirements in the Fire } \\
\text { safety program. }\end{array}$ & Yes & FMC/PMC & $\begin{array}{l}\text { The Fire Safety (FS) Program is documented in } \\
\text { the Fire Protection DAP maintained by ES\&H } \\
\text { Teams } 2 \text { (Site } 200 \text {, which captures the } \\
\text { requirements of the ES\&H Manual. } \\
\text { ES\&H Manual, Document 22.5, Fire. }\end{array}$ \\
\hline & h) & $\begin{array}{l}\text { Adhere to requirements in the } \\
\text { Environmental protection } \\
\text { program. }\end{array}$ & Yes & FMC/PMC & $\begin{array}{l}\text { The Environmental Protection Program is } \\
\text { documented in the Environmental Protection } \\
\text { DAP maintained by ES\&H Teams } 2 \text { (Site 200), } \\
\text { which captures the requirements of the ES\&H } \\
\text { Manual. The electronic IWS system documents } \\
\text { NEPA and other environmental reviews. More } \\
\text { information regarding the environmental } \\
\text { protection program can be found in Volume II } \\
\text { of the ES\&H Manual, Document } 30.1 \text {. }\end{array}$ \\
\hline & i) & $\begin{array}{l}\text { Adhere to requirements in the } \\
\text { ALARA program. }\end{array}$ & Yes & FMC/PMC & $\begin{array}{l}\text { CMELS Site } 200 \text { facilities do not require a } \\
\text { formal ALARA program in accordance with the } \\
\text { LLNL ES\&H Manual Document } 20.4 \text { (“LLNL } \\
\text { Occupational Radiation Protection ALARA } \\
\text { Program") since individual occupational } \\
\text { radiation doses in the facility are not likely to } \\
\text { exceed } 100 \text { mrem/year. However, CMELS } \\
\text { FSPs stress ALARA goals, and CMELS-330 } \\
\text { requires RIs to integrate ALARA philosophy } \\
\text { into operations. }\end{array}$ \\
\hline
\end{tabular}




\section{Conduct of Operations Applicability Matrix for Low Hazard Facilities}

\begin{tabular}{|c|c|c|c|c|c|}
\hline $\begin{array}{l}\text { ES\&H MANUAL } \\
\text { DOCUMENT } 3.5 \\
\text { SECTION } \\
\end{array}$ & & $\begin{array}{l}\text { REQUISITES FOR SECTION } \\
\text { ELEMENTS }\end{array}$ & $\begin{array}{l}\text { APPLICABLE } \\
\text { YES/NO }\end{array}$ & $\begin{array}{l}\text { RESPONSIBILITY } \\
\text { FOR } \\
\text { COMPLIANCE } \\
\text { FMC/PMC }^{1} \\
\end{array}$ & $\begin{array}{l}\text { COMMENTS AND/OR REFERENCE FOR } \\
\text { VERIFICATION OF COMPLIANCE }\end{array}$ \\
\hline $\begin{array}{l}\text { 2.2.3. Operator } \\
\text { Inspection Tours }\end{array}$ & a) & $\begin{array}{l}\text { Procedures for Operator/FC tours } \\
\text { should follow the guidance in } \\
\text { Section 2.2.3. }\end{array}$ & No & NA & $\begin{array}{l}\text { Daily shift tours are not utilized in these } \\
\text { facilities due to the low anticipated } \\
\text { consequences of delayed discovery of } \\
\text { abnormal conditions. }\end{array}$ \\
\hline $\begin{array}{l}\text { 2.2.4. Round/Tour } \\
\text { Inspection Sheets }\end{array}$ & a) & $\begin{array}{l}\text { Procedures for Round/Tour } \\
\text { Inspection Sheets should follow } \\
\text { the guidance in Section 2.2.4. }\end{array}$ & No & NA & $\begin{array}{l}\text { Daily shift tours are not utilized in these } \\
\text { facilities due to the low anticipated } \\
\text { consequences of delayed discovery of } \\
\text { abnormal conditions. }\end{array}$ \\
\hline \multirow[t]{2}{*}{$\begin{array}{l}\text { 2.2.5. Personnel } \\
\text { Protection }\end{array}$} & a) & $\begin{array}{l}\text { In addition to the discussion in } \\
\text { Section 2.2.2 (Safety Practices), } \\
\text { applicable personnel } \\
\text { training/qualification should } \\
\text { include the guidance in Section } \\
2.2 .5 \text {. }\end{array}$ & Yes & FMC/PMC & $\begin{array}{l}\text { Operations personnel are trained to understand } \\
\text { and comply with all area postings for exposure } \\
\text { warnings and PPE requirements. }\end{array}$ \\
\hline & & $\begin{array}{l}\text { Supervisors should review } \\
\text { exposure trends. }\end{array}$ & Yes & FMC/PMC & $\begin{array}{l}\text { Document 20.4, "LLNL Occupational Radiation } \\
\text { Protection ALARA Program," requires ES\&H } \\
\text { Team Health Physicists submittal of notable } \\
\text { trends or ALARA issues to facility and program } \\
\text { management when facilities have established } \\
\text { ALARA goals. }\end{array}$ \\
\hline $\begin{array}{l}\text { 2.2.6. Response to } \\
\text { Indications }\end{array}$ & a) & $\begin{array}{l}\text { Response to Indications should } \\
\text { follow the guidance in Section } \\
\text { 2.2.6. }\end{array}$ & Yes & FMC/PMC & $\begin{array}{l}\text { Indicators important to the safe operation of } \\
\text { systems and the desired response to abnormal } \\
\text { readings are identified in applicable safety } \\
\text { plans. }\end{array}$ \\
\hline $\begin{array}{l}\text { 2.2.7. Resetting } \\
\text { Protective Devices }\end{array}$ & & $\begin{array}{l}\text { Establish controls for resetting } \\
\text { protective devices whose } \\
\text { improper positioning/ operation } \\
\text { could result in an impact to health, } \\
\text { safety, the environment,. }\end{array}$ & Yes & FMC/PMC & $\begin{array}{l}\text { Protective devices (other than circuit breakers, } \\
\text { GFCls, and fuses) and the appropriate } \\
\text { response to a trip condition are identified in } \\
\text { applicable safety plans. Section } 8.2 \text { of ES\&H } \\
\text { Manual Document } 16.1 \text { "Electrical Safety } \\
\text { Program" recommends supplemental training } \\
\text { for workers who reset overcurrent protective } \\
\text { devices. }\end{array}$ \\
\hline
\end{tabular}




\section{Conduct of Operations Applicability Matrix for Low Hazard Facilities}

\begin{tabular}{|c|c|c|c|c|c|}
\hline $\begin{array}{l}\text { ES\&H MANUAL } \\
\text { DOCUMENT } 3.5 \\
\text { SECTION }\end{array}$ & & $\begin{array}{c}\text { REQUISITES FOR SECTION } \\
\text { ELEMENTS }\end{array}$ & $\begin{array}{l}\text { APPLICABLE } \\
\text { YES/NO }\end{array}$ & $\begin{array}{c}\text { RESPONSIBILITY } \\
\text { FOR } \\
\text { COMPLIANCE } \\
\text { FMC/PMC }^{1} \\
\end{array}$ & $\begin{array}{l}\text { COMMENTS AND/OR REFERENCE FOR } \\
\text { VERIFICATION OF COMPLIANCE }\end{array}$ \\
\hline 2.2.8. Load Changes & b) & $\begin{array}{l}\text { Establish that load changes have } \\
\text { been addressed. }\end{array}$ & No & NA & $\begin{array}{l}\text { This attribute is not applicable (i.e. these } \\
\text { facilities do not perform load changes). }\end{array}$ \\
\hline $\begin{array}{l}\text { 2.2.9. Authority to } \\
\text { Operate Equipment }\end{array}$ & a) & $\begin{array}{l}\text { Identify personnel authorized to } \\
\text { operate facility equipment whose } \\
\text { improper operation could result in } \\
\text { an impact to health, safety, the } \\
\text { environment,.. }\end{array}$ & Yes & FMC & $\begin{array}{l}\text { Operation of all Plant Equipment (regardless of } \\
\text { impact) requires approval of Facility Point of } \\
\text { Contact. RHWM personnel are approved to } \\
\text { operate non-hazardous wastewater retention } \\
\text { systems according to documented operating } \\
\text { procedures. }\end{array}$ \\
\hline $\begin{array}{l}\text { 2.2.10. Shift } \\
\text { Operating Bases }\end{array}$ & a) & $\begin{array}{l}\text { Establish shift operating bases for } \\
\text { each shift position. }\end{array}$ & No & NA & $\begin{array}{l}\text { Facilities don't contain operations or equipment } \\
\text { that warrant designation of a shift operating } \\
\text { base. }\end{array}$ \\
\hline $\begin{array}{l}\text { 2.2.11. Potentially } \\
\text { Distractive Written } \\
\text { Material and Devices }\end{array}$ & b) & $\begin{array}{l}\text { Identify controls for Potentially } \\
\text { Distractive Written Material and } \\
\text { Devices. }\end{array}$ & No & NA & $\begin{array}{l}\text { Facilities don't contain operations or equipment } \\
\text { that could result in significant impact to ES\&H } \\
\text { or programs that warrant these controls. }\end{array}$ \\
\hline \multicolumn{6}{|l|}{$\begin{array}{l}\text { CONTROL AREA } \\
\text { ACTIVITIES FOR } \\
\text { DOE FACILITIES } \\
\text { SECTION } 3.0 \\
\end{array}$} \\
\hline $\begin{array}{l}\text { 3.2.1. Control Area } \\
\text { Access }\end{array}$ & a) & $\begin{array}{l}\text { Control rooms associated with } \\
\text { systems, equipment or processes } \\
\text { where operator error could result } \\
\text { in significant impact to health, } \\
\text { safety, the environment or to } \\
\text { programs are identified and } \\
\text { physically delineated }\end{array}$ & Yes & FMC/PMC & $\begin{array}{l}\text { CMELS has identified the control room of the } \\
\text { B190 accelerator. } \\
\text { Identified in FSP } 190 .\end{array}$ \\
\hline
\end{tabular}




\section{Conduct of Operations Applicability Matrix for Low Hazard Facilities}

\begin{tabular}{|c|c|c|c|c|c|}
\hline $\begin{array}{l}\text { ES\&H MANUAL } \\
\text { DOCUMENT } 3.5 \\
\text { SECTION }\end{array}$ & & $\begin{array}{c}\text { REQUISITES FOR SECTION } \\
\text { ELEMENTS }\end{array}$ & $\begin{array}{l}\text { APPLICABLE } \\
\text { YES/NO }\end{array}$ & $\begin{array}{c}\text { RESPONSIBILITY } \\
\text { FOR } \\
\text { COMPLIANCE } \\
\text { FMC/PMC }^{1} \\
\end{array}$ & $\begin{array}{l}\text { COMMENTS AND/OR REFERENCE FOR } \\
\text { VERIFICATION OF COMPLIANCE }\end{array}$ \\
\hline & b) & $\begin{array}{l}\text { Specify personnel who are } \\
\text { authorized for access to control } \\
\text { rooms }\end{array}$ & Yes & FMC/PMC & $\begin{array}{l}\text { Only activities related to the operation or } \\
\text { specifically authorized by management shall be } \\
\text { authorized in the control room when the } \\
\text { equipment or system is being operated. } \\
\text { CMELS-330, FSP } 190 \text { and the ES\&H Manual } \\
2.1 \text {. }\end{array}$ \\
\hline $\begin{array}{l}\text { 3.2.2. Professional } \\
\text { behavior }\end{array}$ & a) & $\begin{array}{l}\text { Control room activities are limited } \\
\text { to those essential for supporting } \\
\text { operations. }\end{array}$ & Yes & FMC/PMC & $\begin{array}{l}\text { Controls for behavior are set in the IWS, } \\
\text { CMELS-330, FSP } 190 \text { and the ES\&H Manual } \\
2.1 .\end{array}$ \\
\hline $\begin{array}{l}\text { 3.2.3. Monitoring the } \\
\text { Main Control Panels }\end{array}$ & a) & $\begin{array}{l}\text { Responsible operators should } \\
\text { understand their responsibility for } \\
\text { monitoring control room panels, } \\
\text { including timely response to alarm } \\
\text { conditions. }\end{array}$ & Yes & FMC/PMC & $\begin{array}{l}\text { A dedicated detector for quality control of the } \\
\text { entire system is provided. This detector's sole } \\
\text { function is to continuously monitor an internal } \\
\text { source. FSP190. }\end{array}$ \\
\hline $\begin{array}{l}\text { 3.2.4. Control } \\
\text { Operator Ancillary } \\
\text { Duties }\end{array}$ & a) & $\begin{array}{l}\text { Ancillary duties should not } \\
\text { interfere with the operators' shift } \\
\text { responsibilities. }\end{array}$ & Yes & FMC/PMC & $\begin{array}{l}\text { Controls for ancillary duties are set in the IWS, } \\
\text { CMELS-330, FSP } 190 \text { and the ES\&H Manual } \\
2.1 \text {. }\end{array}$ \\
\hline $\begin{array}{l}\text { 3.2.5. Operation of } \\
\text { Control Area } \\
\text { Equipment }\end{array}$ & a) & $\begin{array}{l}\text { Only authorized personnel shall } \\
\text { operate control area equipment. }\end{array}$ & Yes & FMC/PMC & $\begin{array}{l}\text { FSP-190 Section } 6.10 \text { "The B-190 Facility } \\
\text { Manager determines an operators qualification } \\
\text { level. A current list of authorized RGD } \\
\text { operators shall be kept in the CAMS office." }\end{array}$ \\
\hline \multicolumn{6}{|l|}{$\begin{array}{l}\text { COMMUNICATIONS } \\
\text { SECTION } 4.0\end{array}$} \\
\hline $\begin{array}{l}\text { 4.2.1. Emergency } \\
\text { Communications } \\
\text { Systems }\end{array}$ & a) & $\begin{array}{l}\text { Ensure ready notification of } \\
\text { workers during routine and } \\
\text { emergency conditions. }\end{array}$ & Yes & FMC & $\begin{array}{l}\text { Building intercom, emergency paging system, } \\
\text { postings on equipment or facility entrances, or } \\
\text { emergency bullhorns are available. An } \\
\text { emergency call list is maintained by Fire } \\
\text { Dispatch and updated by the building H\&S } \\
\text { Technicians. } \\
\text { Document } 22.1 \text {, Emergency Preparedness and } \\
\text { Response. }\end{array}$ \\
\hline
\end{tabular}




\section{Conduct of Operations Applicability Matrix for Low Hazard Facilities}

\begin{tabular}{|c|c|c|c|c|c|}
\hline $\begin{array}{l}\text { ES\&H MANUAL } \\
\text { DOCUMENT } 3.5 \\
\text { SECTION }\end{array}$ & & $\begin{array}{c}\text { REQUISITES FOR SECTION } \\
\text { ELEMENTS }\end{array}$ & $\begin{array}{l}\text { APPLICABLE } \\
\text { YES/NO }\end{array}$ & $\begin{array}{c}\text { RESPONSIBILITY } \\
\text { FOR } \\
\text { COMPLIANCE } \\
\text { FMC/PMC }^{1} \\
\end{array}$ & $\begin{array}{l}\text { COMMENTS AND/OR REFERENCE FOR } \\
\text { VERIFICATION OF COMPLIANCE }\end{array}$ \\
\hline & & & & & $\begin{array}{l}\text { Plant Engineering conducts routine PM and } \\
\text { testing of alarm systems. }\end{array}$ \\
\hline & b) & $\begin{array}{l}\text { Emergency communications are } \\
\text { regularly tested for functionality. }\end{array}$ & Yes & FMC/PMC & $\begin{array}{l}\text { LLNL Site emergency communications systems } \\
\text { are tested daily by the LLNL Alarms Division } \\
\text { (Facility Management should ensure that } \\
\text { emergency communications can be heard in } \\
\text { the facility). }\end{array}$ \\
\hline $\begin{array}{l}\text { 4.2.2. Public } \\
\text { Address System }\end{array}$ & a) & $\begin{array}{l}\text { Public Address system is } \\
\text { administratively controlled. }\end{array}$ & Yes & $\mathrm{PMC} / \mathrm{FMC}$ & $\begin{array}{l}\text { LLNL Alarms Division controls the Site } \\
\text { emergency communication system. }\end{array}$ \\
\hline \multirow[t]{4}{*}{$\begin{array}{l}\text { 4.2.3. Contacting } \\
\text { Operators }\end{array}$} & a) & $\begin{array}{l}\text { Provide functional communication } \\
\text { devices (telephones, paging } \\
\text { systems) within the facility and } \\
\text { immediate area. }\end{array}$ & Yes & FMC & $\begin{array}{l}\text { Telephones throughout occupied facilities, } \\
\text { emergency paging system, radio pagers, two- } \\
\text { way radios for facility operations staff and } \\
\text { electronic mail provide rapid communications. }\end{array}$ \\
\hline & b) & $\begin{array}{l}\text { Provide safety alarms. Visual } \\
\text { alarms should be used in noisy } \\
\text { areas where audible alarms may } \\
\text { go unnoticed. }\end{array}$ & Yes & FMC & $\begin{array}{l}\text { Malfunctions of the telephones, building paging } \\
\text { system, pagers, and electronic mail are } \\
\text { infrequent. Telephone, alarms, and radio page } \\
\text { systems have either battery or emergency } \\
\text { back-up power. } \\
\text { ES\&H Manual, Document } 12.1 \text {. }\end{array}$ \\
\hline & c) & $\begin{array}{l}\text { Communication systems should } \\
\text { be available in remote areas } \\
\text { where work is conducted, such as } \\
\text { basements, lofts, and equipment } \\
\text { rooms. }\end{array}$ & Yes & FMC & $\begin{array}{l}\text { Building intercom and radio page provide } \\
\text { coverage in out-of the-way portions of the } \\
\text { facilities. }\end{array}$ \\
\hline & d) & $\begin{array}{l}\text { As appropriate, provisions should } \\
\text { exist for locating key workers } \\
\text { during off-hours, and during the } \\
\text { workday while they are outside } \\
\text { the facility. }\end{array}$ & Yes & FMC/PMC & $\begin{array}{l}\text { Key operational personnel can be reached via } \\
\text { radio pager and government-owned cellular } \\
\text { telephone systems. Lists of emergency contact } \\
\text { numbers are maintained by the CMELS payroll } \\
\text { organizations. }\end{array}$ \\
\hline
\end{tabular}




\section{Conduct of Operations Applicability Matrix for Low Hazard Facilities}

\begin{tabular}{|c|c|c|c|c|c|}
\hline $\begin{array}{l}\text { ES\&H MANUAL } \\
\text { DOCUMENT } 3.5 \\
\text { SECTION } \\
\end{array}$ & & $\begin{array}{c}\text { REQUISITES FOR SECTION } \\
\text { ELEMENTS }\end{array}$ & $\begin{array}{l}\text { APPLICABLE } \\
\text { YES/NO }\end{array}$ & $\begin{array}{c}\text { RESPONSIBILITY } \\
\text { FOR } \\
\text { COMPLIANCE } \\
\text { FMC/PMC }^{1} \\
\end{array}$ & $\begin{array}{c}\text { COMMENTS AND/OR REFERENCE FOR } \\
\text { VERIFICATION OF COMPLIANCE }\end{array}$ \\
\hline 4.2.4. Radios & a) & $\begin{array}{l}\text { Areas where radios are prohibited } \\
\text { should be delineated. }\end{array}$ & Yes & FMC/PMC & Areas where radios are prohibited are posted. \\
\hline $\begin{array}{l}\text { 4.2.5. Abbreviations } \\
\text { and Acronyms }\end{array}$ & a) & $\begin{array}{l}\text { In emergency communications, } \\
\text { limit use of abbreviations and } \\
\text { acronyms to those in approved } \\
\text { LLNL documents. }\end{array}$ & Yes & $\mathrm{FMC} / \mathrm{PMC}$ & $\begin{array}{l}\text { LLNL Alarms Division controls the Site } \\
\text { emergency communication system and as a } \\
\text { general rule do not use acronyms in emergency } \\
\text { communications. }\end{array}$ \\
\hline $\begin{array}{l}\text { 4.2.6. Oral } \\
\text { instructions and } \\
\text { Informal } \\
\text { Communications }\end{array}$ & a) & $\begin{array}{l}\text { Oral Instructions and } \\
\text { Informational Communications } \\
\text { should follow the guidance in } \\
\text { Section 4.2.6. }\end{array}$ & Yes & FMC/PMC & $\begin{array}{l}\text { Oral instructions involving equipment } \\
\text { operations should be clear and concise. }\end{array}$ \\
\hline \multicolumn{6}{|l|}{$\begin{array}{l}\text { CONTROL OF ON- } \\
\text { SHIFT TRAINING } \\
\text { SECTION } 5.0\end{array}$} \\
\hline $\begin{array}{l}\text { 5.2.1. Adherence to } \\
\text { Training Programs }\end{array}$ & & Identify tasks requiring OJT. & Yes & PMC & $\begin{array}{l}\text { OJT requirements are identified in Document } \\
40.1 \text {, "LLNL Training Program Manual," and } \\
\text { CMELS- } 330 \text {. CMELS- } 330 \text { requires the RI to } \\
\text { ensure required training, including on-the-job } \\
\text { training (OJT), is completed and to ensure } \\
\text { workers have necessary qualifications. ES\&H } \\
\text { Document } 17.7 \text { requires formal OJT training for } \\
\text { explosives handlers at Site } 200 \text {. }\end{array}$ \\
\hline
\end{tabular}




\section{Conduct of Operations Applicability Matrix for Low Hazard Facilities}

\begin{tabular}{|c|c|c|c|c|c|}
\hline $\begin{array}{l}\text { ES\&H MANUAL } \\
\text { DOCUMENT } 3.5 \\
\text { SECTION }\end{array}$ & & $\begin{array}{c}\text { REQUISITES FOR SECTION } \\
\text { ELEMENTS }\end{array}$ & $\begin{array}{l}\text { APPLICABLE } \\
\text { YES/NO }\end{array}$ & $\begin{array}{c}\text { RESPONSIBILITY } \\
\text { FOR } \\
\text { COMPLIANCE } \\
\text { FMC/PMC }^{1} \\
\end{array}$ & $\begin{array}{l}\text { COMMENTS AND/OR REFERENCE FOR } \\
\text { VERIFICATION OF COMPLIANCE }\end{array}$ \\
\hline $\begin{array}{l}\text { 5.2.2. On-shift } \\
\text { Instructor } \\
\text { Qualifications }\end{array}$ & & $\begin{array}{l}\text { Document instructor and } \\
\text { evaluator qualifications. }\end{array}$ & Yes & PMC & $\begin{array}{l}\text { Qualifications for OJT training instructors are } \\
\text { determined by education, experience, } \\
\text { background, subject area knowledge, and the } \\
\text { ability to instruct others. Al and RI specify } \\
\text { individuals authorized to conduct OJT for } \\
\text { specific facilities, equipment, or operations. } \\
\text { Completions of formal degree programs are } \\
\text { documented in personnel records. Completions } \\
\text { of classes during LLNL employment are } \\
\text { recorded in LTRAIN. } \\
\text { ES\&H Manual Document } 40.1 \text {. }\end{array}$ \\
\hline \multirow[t]{2}{*}{$\begin{array}{l}\text { 5.2.3. Qualified } \\
\text { Operator Supervision } \\
\text { and Control of } \\
\text { Trainees }\end{array}$} & a) & $\begin{array}{l}\text { Establish protocol for supervision } \\
\text { and control of trainees. }\end{array}$ & Yes & PMC & $\begin{array}{l}\text { FSPs, IWS/SPs, and/or IWSs define (as } \\
\text { appropriate) conditions under which trainees } \\
\text { may be used to support potentially hazardous } \\
\text { work activities. The IWS lists names of qualified } \\
\text { personnel to do the work activity. }\end{array}$ \\
\hline & b) & $\begin{array}{l}\text { Ensure trainee awareness of } \\
\text { hazards and operating limits. }\end{array}$ & Yes & PMC & $\begin{array}{l}\text { CMELS-330 requires the RI to ensure that } \\
\text { trainees only work according to existing } \\
\text { procedures and IWSs, and that they are aware } \\
\text { of operating limits and hazards. CMELS- } 330 \\
\text { requires the RI to ensure visitors, guests, } \\
\text { students, and vendors either have the required } \\
\text { training or work under the direct supervision of } \\
\text { a qualified worker. }\end{array}$ \\
\hline $\begin{array}{l}\text { 5.2.4. Operator } \\
\text { Qualification Program } \\
\text { Approval }\end{array}$ & & $\begin{array}{l}\text { Ensure the appropriate area } \\
\text { supervisor has approved the OJT. }\end{array}$ & Yes & PMC & $\begin{array}{l}\text { The RI documents and either provides or } \\
\text { approves OJT for personnel working under their } \\
\text { direction. This process is reflected in the IWS } \\
\text { authorizing the work. } \\
\text { Formal OJT programs, such as Explosive } \\
\text { Handler Qualifications (e.g. Document 17.7), } \\
\text { may substitute for the RI documentation } \\
\text { specified above. }\end{array}$ \\
\hline
\end{tabular}




\section{Conduct of Operations Applicability Matrix for Low Hazard Facilities}

\begin{tabular}{|c|c|c|c|c|c|}
\hline $\begin{array}{l}\text { ES\&H MANUAL } \\
\text { DOCUMENT } 3.5 \\
\text { SECTION }\end{array}$ & & $\begin{array}{c}\text { REQUISITES FOR SECTION } \\
\text { ELEMENTS }\end{array}$ & $\begin{array}{l}\text { APPLICABLE } \\
\text { YES/NO }\end{array}$ & $\begin{array}{c}\text { RESPONSIBILITY } \\
\text { FOR } \\
\text { COMPLIANCE } \\
\text { FMC/PMC }^{1} \\
\end{array}$ & $\begin{array}{l}\text { COMMENTS AND/OR REFERENCE FOR } \\
\text { VERIFICATION OF COMPLIANCE }\end{array}$ \\
\hline $\begin{array}{l}\text { 5.2.5. Training } \\
\text { Documentation }\end{array}$ & & Document OJT. & Yes & PMC & $\begin{array}{l}\text { OJT training is documented in the Training } \\
\text { Qualification Record maintained by the payroll } \\
\text { supervisor in accordance with Document } 40.1 \text {, } \\
\text { "LLNL Training Program Manual." CMELS-330 } \\
\text { defines record keeping requirements for } \\
\text { training records. }\end{array}$ \\
\hline $\begin{array}{l}\text { 5.2.6. Suspension of } \\
\text { Training }\end{array}$ & a) & $\begin{array}{l}\text { Ensure trainees understand their } \\
\text { role during abnormal conditions. }\end{array}$ & Yes & FMC/PMC & $\begin{array}{l}\text { CMELS-330 requires the RI to ensure that } \\
\text { trainees only work with experienced personnel } \\
\text { according to existing procedures, and that they } \\
\text { are aware of operating limits and hazards. } \\
\text { CMELS-330 requires the host and RI to ensure } \\
\text { visitors, guests, students, and vendors either } \\
\text { have the required training or are escorted. }\end{array}$ \\
\hline $\begin{array}{l}\text { 5.2.7. Maximum } \\
\text { Number of Trainees }\end{array}$ & & $\begin{array}{l}\text { Establish limits for the number of } \\
\text { OJT trainees. }\end{array}$ & No & NA & $\begin{array}{l}\text { CMELS does not limit the number of OJT } \\
\text { trainees. OJT requirements are identified in } \\
\text { Document } 40.1 \text {, "LLNL Training Program } \\
\text { Manual," and CMELS- } 330 \text { requires the RI to } \\
\text { ensure required training, including on-the-job } \\
\text { training (OJT) for all trainees, is completed and } \\
\text { to ensure workers have necessary } \\
\text { qualifications. ES\&H Document } 17.7 \text { requires } \\
\text { formal OJT training for explosives handlers at } \\
\text { Site } 200 \text {. }\end{array}$ \\
\hline \multicolumn{6}{|l|}{$\begin{array}{c}\text { INVESTIGATION OF } \\
\text { ABNORMAL } \\
\text { EVENTS } \\
\text { SECTION } 6.0 \\
\end{array}$} \\
\hline $\begin{array}{l}\text { 6.2.1. Events } \\
\text { Requiring } \\
\text { Investigation }\end{array}$ & & $\begin{array}{l}\text { Identify types of events that } \\
\text { require investigation }\end{array}$ & Yes & FMC/PMC & $\begin{array}{l}\text { LLNL ES\&H Manual, Document 4.3, (LLNL } \\
\text { Implementation Procedure for Reporting } \\
\text { Occurrences to the Department of Energy } \\
\text { (DOE) Order 231.1A, "Environment, Safety and } \\
\text { Health Reporting," and DOE Manual 231.1-2, } \\
\text { "Occurrence Reporting and Processing of } \\
\text { Operations Information." }\end{array}$ \\
\hline
\end{tabular}




\section{Conduct of Operations Applicability Matrix for Low Hazard Facilities}

\begin{tabular}{|c|c|c|c|c|c|}
\hline $\begin{array}{l}\text { ES\&H MANUAL } \\
\text { DOCUMENT } 3.5 \\
\text { SECTION }\end{array}$ & & $\begin{array}{c}\text { REQUISITES FOR SECTION } \\
\text { ELEMENTS }\end{array}$ & $\begin{array}{l}\text { APPLICABLE } \\
\text { YES/NO }\end{array}$ & $\begin{array}{c}\text { RESPONSIBILITY } \\
\text { FOR } \\
\text { COMPLIANCE } \\
\text { FMC/PMC }^{1}\end{array}$ & $\begin{array}{l}\text { COMMENTS AND/OR REFERENCE FOR } \\
\text { VERIFICATION OF COMPLIANCE }\end{array}$ \\
\hline $\begin{array}{l}\text { 6.2.2. Investigation } \\
\text { Responsibility }\end{array}$ & & $\begin{array}{l}\text { Identify Event Investigation } \\
\text { responsibilities }\end{array}$ & Yes & FMC/PMC & $\begin{array}{l}\text { CMELS-330 requires that the AD utilize the } \\
\text { Assurance Manager to ensure that incident } \\
\text { response, analysis, and recording conform to } \\
\text { requirements of the LLNL ES\&H Manual. } \\
\text { CMS-322 specifies processes for investigation } \\
\text { of abnormal events in accordance with the } \\
\text { LLNL ES\&H Manual, Document 4.3, (LLNL } \\
\text { Implementation Procedure for Reporting } \\
\text { Occurrences to the Department of Energy } \\
\text { (DOE) Order 231.1A, "Environment, Safety and } \\
\text { Health Reporting," and DOE Manual 231.1-2, } \\
\text { "Occurrence Reporting and Processing of } \\
\text { Operations Information." }\end{array}$ \\
\hline $\begin{array}{l}\text { 6.2.3. Investigator } \\
\text { Qualification }\end{array}$ & a) & $\begin{array}{l}\text { Investigators complete training } \\
\text { requirements }\end{array}$ & Yes & FMC/PMC & $\begin{array}{l}\text { ES\&H Manual Document } 4.6 \text { specifies training } \\
\text { requirements. }\end{array}$ \\
\hline $\begin{array}{l}\text { 6.2.4. Information to } \\
\text { be Gathered }\end{array}$ & a) & Collect required information & Yes & $\mathrm{FMC/PMC}$ & $\begin{array}{l}\text { ES\&H Manual Document } 4.6 \text { specifies } \\
\text { investigation procedures. }\end{array}$ \\
\hline $\begin{array}{l}\text { 6.2.5. Event } \\
\text { Investigation }\end{array}$ & & $\begin{array}{l}\text { Conduct structured review of } \\
\text { events }\end{array}$ & Yes & FMC/PMC & $\begin{array}{l}\text { CMELS-330 requires that the AD utilize the } \\
\text { Assurance Manager to ensure that incident } \\
\text { response, analysis, and recording conform to } \\
\text { requirements of the LLNL ES\&H Manual. } \\
\text { CMELS-330 specifies processes for } \\
\text { investigation of abnormal events in accordance } \\
\text { with the LLNL ES\&H Manual, Document } 4.3 \text {, } \\
\text { (LLNL Implementation Procedure for Reporting } \\
\text { Occurrences to the Department of Energy } \\
\text { (DOE) Order 231.1A, "Environment, Safety and } \\
\text { Health Reporting," and DOE Manual 231.1-2, } \\
\text { "Occurrence Reporting and Processing of } \\
\text { Operations Information." }\end{array}$ \\
\hline
\end{tabular}




\section{Conduct of Operations Applicability Matrix for Low Hazard Facilities}

\begin{tabular}{|c|c|c|c|c|c|}
\hline $\begin{array}{l}\text { ES\&H MANUAL } \\
\text { DOCUMENT } 3.5 \\
\text { SECTION }\end{array}$ & & $\begin{array}{l}\text { REQUISITES FOR SECTION } \\
\text { ELEMENTS }\end{array}$ & $\begin{array}{l}\text { APPLICABLE } \\
\text { YES/NO }\end{array}$ & $\begin{array}{l}\text { RESPONSIBILITY } \\
\text { FOR } \\
\text { COMPLIANCE } \\
\text { FMC/PMC }^{1}\end{array}$ & $\begin{array}{l}\text { COMMENTS AND/OR REFERENCE FOR } \\
\text { VERIFICATION OF COMPLIANCE }\end{array}$ \\
\hline $\begin{array}{l}\text { 6.2.6. Investigative } \\
\text { Report }\end{array}$ & a) & Prepare investigative reports & Yes & FMC/PMC & $\begin{array}{l}\text { CMELS-330 requires that the AD utilize the } \\
\text { Assurance Manager to ensure that incident } \\
\text { response, analysis, and recording conform to } \\
\text { requirements of the LLNL ES\&H Manual. } \\
\text { CMELS-330 specifies processes for } \\
\text { investigation of abnormal events in accordance } \\
\text { with the LLNL ES\&H Manual, Document } 4.3 \text {, } \\
\text { (LLNL Implementation Procedure for Reporting } \\
\text { Occurrences to the Department of Energy } \\
\text { (DOE) Order 231.1A, "Environment, Safety and } \\
\text { Health Reporting," and DOE Manual 231.1-2, } \\
\text { "Occurrence Reporting and Processing of } \\
\text { Operations Information." }\end{array}$ \\
\hline 6.2.7. Event Training & & $\begin{array}{l}\text { Evaluate events for training } \\
\text { benefit and conduct the } \\
\text { appropriate training }\end{array}$ & Yes & FMC/PMC & $\begin{array}{l}\text { Need for training is considered as part of the } \\
\text { process described in ES\&H Manual Document } \\
\text { 4.6. }\end{array}$ \\
\hline \multirow[t]{2}{*}{ 6.2.8. Event Trending } & a) & $\begin{array}{l}\text { Patterns of deficiencies should be } \\
\text { trended and a report (causes and } \\
\text { trends) provided to the } \\
\text { management chain. }\end{array}$ & Yes & PMC & $\begin{array}{l}\text { CMELS-330 defines provisions for } \\
\text { reviewing/analyzing safety data within the } \\
\text { Directorate. CMS- } 305 \text { defines provisions for } \\
\text { rolling up data to the Institutional level for } \\
\text { trending. } \\
\text { Trend analysis requirements are included in } \\
\text { CMELS-305, "ES\&H Self-Assessment Plan." }\end{array}$ \\
\hline & b) & $\begin{array}{l}\text { Information in the event trending } \\
\text { report should be communicated to } \\
\text { appropriate facility personnel }\end{array}$ & Yes & PMC & $\begin{array}{l}\text { Reports are provided to FMs per ES\&H Manua } \\
\text { Document 4.1. }\end{array}$ \\
\hline
\end{tabular}




\section{Conduct of Operations Applicability Matrix for Low Hazard Facilities}

\begin{tabular}{|c|c|c|c|c|}
\hline $\begin{array}{l}\text { ES\&H MANUAL } \\
\text { DOCUMENT } 3.5 \\
\text { SECTION }\end{array}$ & $\begin{array}{c}\text { REQUISITES FOR SECTION } \\
\text { ELEMENTS }\end{array}$ & $\begin{array}{l}\text { APPLICABLE } \\
\text { YES/NO }\end{array}$ & $\begin{array}{c}\text { RESPONSIBILITY } \\
\text { FOR } \\
\text { COMPLIANCE } \\
\text { FMC/PMC }^{1} \\
\end{array}$ & $\begin{array}{l}\text { COMMENTS AND/OR REFERENCE FOR } \\
\text { VERIFICATION OF COMPLIANCE }\end{array}$ \\
\hline 6.2.9. Sabotage & $\begin{array}{l}\text { a) Response and investigative } \\
\text { procedures for suspected } \\
\text { sabotage should include the } \\
\text { guidance in Section 6.2.9. }\end{array}$ & Yes & $\mathrm{FMC/PMC}$ & $\begin{array}{l}\text { ES\&H Manual Documents 4.5, } 4.6 \text { and } 4.7 \\
\text { (Incidents - Notification, Analysis, and } \\
\text { Reporting; Incident Analysis Manual; and ES\&H } \\
\text { Analysis Methods) will be followed. CMELS-330 } \\
\text { specifies processes for investigation of } \\
\text { abnormal events. } \\
\text { ES\&H Manual, Document 22.1, Emergency } \\
\text { Preparedness and Response. }\end{array}$ \\
\hline \multicolumn{5}{|l|}{$\begin{array}{l}\text { NOTIFICATIONS } \\
\text { SECTION } 7.0\end{array}$} \\
\hline $\begin{array}{l}\text { 7.2.1. Notification } \\
\text { Procedures }\end{array}$ & a) Establish notification procedures. & Yes & FMC/PMC & $\begin{array}{l}\text { All personnel working in CMELS facilities and } \\
\text { personnel working on CMELS activities in non- } \\
\text { CMELS facilities and at offsite locations are } \\
\text { responsible to notify the Facility Point of } \\
\text { Contact (FPOC) and their division management } \\
\text { of any unplanned events or unexpected } \\
\text { conditions that could potentially be reportable } \\
\text { (per CMELS-330). } \\
\text { ES\&H Manual, Document 4.3, LLNL } \\
\text { Implementation Procedure for Reporting } \\
\text { Occurrences to DOE. }\end{array}$ \\
\hline
\end{tabular}




\section{Conduct of Operations Applicability Matrix for Low Hazard Facilities}

\begin{tabular}{|c|c|c|c|c|}
\hline $\begin{array}{l}\text { ES\&H MANUAL } \\
\text { DOCUMENT } 3.5 \\
\text { SECTION }\end{array}$ & $\begin{array}{c}\text { REQUISITES FOR SECTION } \\
\text { ELEMENTS }\end{array}$ & $\begin{array}{l}\text { APPLICABLE } \\
\text { YES/NO }\end{array}$ & $\begin{array}{l}\text { RESPONSIBILITY } \\
\text { FOR } \\
\text { COMPLIANCE } \\
\text { FMC/PMC }^{1}\end{array}$ & $\begin{array}{l}\text { COMMENTS AND/OR REFERENCE FOR } \\
\text { VERIFICATION OF COMPLIANCE }\end{array}$ \\
\hline $\begin{array}{l}\text { 7.2.2.Notification } \\
\text { Responsibility }\end{array}$ & $\begin{array}{l}\text { a) Identify the individual (facility } \\
\text { management or program } \\
\text { management) responsible for } \\
\text { initiating the notification process. }\end{array}$ & Yes & FMC/PMC & $\begin{array}{l}\text { CMLS-409 (CMELS Site } 200 \text { Employee } \\
\text { Emergency Response Self-Help Guide), and } \\
\text { CMELS-330 identify notification procedure and } \\
\text { reporting chains. } \\
\text { All CMELS operations managers (e.g. FMs, } \\
\text { DDL/Ops, DAD/Ops, Als, etc.) are required to } \\
\text { complete EM2010, "Occurrence Reporting." } \\
\text { Training completions are documented in } \\
\text { LTRAIN. } \\
\text { ES\&H Manual, Document 4.3, LLNL } \\
\text { Implementation Procedure for Reporting } \\
\text { Occurrences to DOE. }\end{array}$ \\
\hline $\begin{array}{l}\text { 7.2.3. Names and } \\
\text { Phone Numbers }\end{array}$ & $\begin{array}{l}\text { a) Contact information for } \\
\text { occurrence reporting is made } \\
\text { available. }\end{array}$ & Yes & FMC/PMC & $\begin{array}{l}\text { CMLS-409 (CMELS Site } 200 \text { Employee } \\
\text { Emergency Response Self-Help Guide), and } \\
\text { CMELS-330 identify notification procedure and } \\
\text { reporting chains, which includes notification of } \\
\text { the Assurance Manager. } \\
\text { LLNL Emergency Contact Roster. }\end{array}$ \\
\hline 7.2.4. Documentation & $\begin{array}{l}\text { a) Maintain a formal record of } \\
\text { notifications. }\end{array}$ & Yes & FMC/PMC & $\begin{array}{l}\text { CMLS-409 (CMELS Site } 200 \text { Employee } \\
\text { Emergency Response Self-Help Guide), and } \\
\text { CMELS-330 identify notification procedure and } \\
\text { reporting chains. } \\
\text { All CMELS operations managers (e.g., FMs, } \\
\text { DDL/Ops, DAD/Ops, Als, etc.) are required to } \\
\text { complete EM2010, "Occurrence Reporting." } \\
\text { Training completions are documented in } \\
\text { LTRAIN. } \\
\text { ES\&H Manual, Document 4.3, LLNL } \\
\text { Implementation Procedure for Reporting } \\
\text { Occurrences to DOE. Formal records of ORPS } \\
\text { notifications are maintained by the Institutional } \\
\text { Occurrence Reporting Manager. }\end{array}$ \\
\hline
\end{tabular}




\section{Conduct of Operations Applicability Matrix for Low Hazard Facilities}

\begin{tabular}{|c|c|c|c|c|c|}
\hline $\begin{array}{l}\text { ES\&H MANUAL } \\
\text { DOCUMENT } 3.5 \\
\text { SECTION } \\
\end{array}$ & & $\begin{array}{c}\text { REQUISITES FOR SECTION } \\
\text { ELEMENTS }\end{array}$ & $\begin{array}{l}\text { APPLICABLE } \\
\text { YES/NO }\end{array}$ & $\begin{array}{c}\text { RESPONSIBILITY } \\
\text { FOR } \\
\text { COMPLIANCE } \\
\text { FMC/PMC }^{1} \\
\end{array}$ & $\begin{array}{l}\text { COMMENTS AND/OR REFERENCE FOR } \\
\text { VERIFICATION OF COMPLIANCE }\end{array}$ \\
\hline $\begin{array}{l}\text { 7.2.5. Communication } \\
\text { Equipment }\end{array}$ & a) & $\begin{array}{l}\text { Maintain communication } \\
\text { equipment adequate for } \\
\text { notification procedure. }\end{array}$ & Yes & FMC & $\begin{array}{l}\text { Communication equipment is maintained by the } \\
\text { Institution. }\end{array}$ \\
\hline \multicolumn{6}{|l|}{$\begin{array}{c}\text { CONTROL OF } \\
\text { EQUIPMENT AND } \\
\text { SYSTEMS STATUS } \\
\text { SECTION } 8.0 \\
\end{array}$} \\
\hline \multirow[t]{2}{*}{$\begin{array}{l}\text { 8.2.1. Status Change } \\
\text { Authorization and } \\
\text { Reporting }\end{array}$} & a) & $\begin{array}{l}\text { Identify equipment and/or systems } \\
\text { whose configuration must be } \\
\text { maintained. }\end{array}$ & Yes & FMC/PMC & $\begin{array}{l}\text { FSPs identify building safety systems (under } \\
\text { Plant Engineering configuration management) } \\
\text { and building safety features (under CMELS } \\
\text { configuration management). Activity specific } \\
\text { controls are identified through the IWS and/or } \\
\text { IWS/SP and may require activity-level QA } \\
\text { plans in accordance with CMLS-901 (Quality } \\
\text { Assurance Plan). CMLS-405 (Configuration } \\
\text { Management Plan) establishes and maintains a } \\
\text { level of Configuration Management (CM) } \\
\text { control for facilities managed by CMELS. } \\
\text { ES\&H Manual, Document 41.2, "Configuration } \\
\text { Management Program Description." }\end{array}$ \\
\hline & b) & $\begin{array}{l}\text { Establish a formal mechanism to } \\
\text { authorize changes in configuration } \\
\text { or status. }\end{array}$ & Yes & FMC/PMC & $\begin{array}{l}\text { An IWS is required for all modifications to } \\
\text { CMELS facilities. Facility Point of Contact } \\
\text { concurrence is required on all IWSs and Plant } \\
\text { Engineering "bridging documents" that would } \\
\text { modify a CMELS facility. CMLS- } 405 \text { documents } \\
\text { the requirements that must be followed for } \\
\text { modifications to all items under CM. When } \\
\text { required, an Explosives Work Permit is used in } \\
\text { the authorization process. }\end{array}$ \\
\hline
\end{tabular}




\section{Conduct of Operations Applicability Matrix for Low Hazard Facilities}

\begin{tabular}{|c|c|c|c|c|c|}
\hline $\begin{array}{l}\text { ES\&H MANUAL } \\
\text { DOCUMENT } 3.5 \\
\text { SECTION }\end{array}$ & & $\begin{array}{c}\text { REQUISITES FOR SECTION } \\
\text { ELEMENTS }\end{array}$ & $\begin{array}{l}\text { APPLICABLE } \\
\text { YES/NO }\end{array}$ & $\begin{array}{c}\text { RESPONSIBILITY } \\
\text { FOR } \\
\text { COMPLIANCE } \\
\text { FMC/PMC }^{1} \\
\end{array}$ & $\begin{array}{l}\text { COMMENTS AND/OR REFERENCE FOR } \\
\text { VERIFICATION OF COMPLIANCE }\end{array}$ \\
\hline & c) & $\begin{array}{l}\text { Establish a formal mechanism to } \\
\text { ensure personnel are kept } \\
\text { informed of any changes in the } \\
\text { operational status of the } \\
\text { equipment or systems. }\end{array}$ & Yes & FMC/PMC & $\begin{array}{l}\text { The IWS process informs of proposed } \\
\text { changes. Prior to the initiation of those facility- } \\
\text { related changes, the FPOCs contact affected } \\
\text { building personnel. For changes to } \\
\text { programmatic equipment, the RI contacts those } \\
\text { personnel who will be affected. }\end{array}$ \\
\hline $\begin{array}{l}\text { 8.2.2. Equipment and } \\
\text { System Alignment }\end{array}$ & a) & $\begin{array}{l}\text { Equipment and systems are } \\
\text { aligned or checked for proper } \\
\text { alignment before operation. }\end{array}$ & Yes & FMC/PMC & $\begin{array}{l}\text { CMELS- } 330 \text { discusses the work authorization } \\
\text { process. The IWS process includes a pre-start } \\
\text { review to ensure everything is ready to go. A } \\
\text { pre-start checklist can be used to help in this } \\
\text { review. The formality of a pre-start review when } \\
\text { required is determined by the Work Activity } \\
\text { Level and the scope of the work. }\end{array}$ \\
\hline $\begin{array}{l}\text { 8.2.3. Equipment } \\
\text { Locking and Tagging }\end{array}$ & a) & $\begin{array}{l}\text { Lockout and tagout procedures } \\
\text { are in place. }\end{array}$ & Yes & FMC/PMC & $\begin{array}{l}\text { Lockout and tagout is implemented through the } \\
\text { IWS process in accordance with Document } \\
12.6 \text { of the LLNL ES\&H Manual. CMELS } \\
\text { Facility Operations personnel do not perform } \\
\text { lockout \& tagout. }\end{array}$ \\
\hline $\begin{array}{l}\text { 8.2.4. Operational } \\
\text { Limits Compliance }\end{array}$ & a) & $\begin{array}{l}\text { Establish administrative controls } \\
\text { that document compliance with } \\
\text { operating limits. }\end{array}$ & Yes & FMC/PMC & $\begin{array}{l}\text { Facility concurrence on work to be conducted as } \\
\text { documented in an IWS, as described in CMELS- } \\
330 \text { and ES\&H Manual Document } 2.1 \text {, is } \\
\text { provided to ensure the activity is within the } \\
\text { safety basis envelope of a facility. } \\
\text { Authorizing Individuals monitor the work to } \\
\text { ensure that hazards are identified, controls are } \\
\text { developed and implemented, and that ES\&H } \\
\text { requirements are met. Where required, } \\
\text { equipment run logs document that operating } \\
\text { limits are observed, that critical measurement } \\
\text { and test equipment is operational, and that } \\
\text { routine maintenance and calibrations are } \\
\text { conducted. }\end{array}$ \\
\hline
\end{tabular}




\section{Conduct of Operations Applicability Matrix for Low Hazard Facilities}

\begin{tabular}{|c|c|c|c|c|}
\hline $\begin{array}{l}\text { ES\&H MANUAL } \\
\text { DOCUMENT } 3.5 \\
\text { SECTION }\end{array}$ & $\begin{array}{l}\text { REQUISITES FOR SECTION } \\
\text { ELEMENTS }\end{array}$ & $\begin{array}{l}\text { APPLICABLE } \\
\text { YES/NO }\end{array}$ & $\begin{array}{c}\text { RESPONSIBILITY } \\
\text { FOR } \\
\text { COMPLIANCE } \\
\text { FMC/PMC }^{1} \\
\end{array}$ & $\begin{array}{l}\text { COMMENTS AND/OR REFERENCE FOR } \\
\text { VERIFICATION OF COMPLIANCE }\end{array}$ \\
\hline $\begin{array}{l}\text { 8.2.5. Equipment } \\
\text { Deficiency } \\
\text { Identification and } \\
\text { Documentation }\end{array}$ & $\begin{array}{l}\text { a) Establish method for identifying, } \\
\text { reporting, and documenting } \\
\text { equipment deficiencies. }\end{array}$ & Yes & FMC/PMC & $\begin{array}{l}\text { CMLS-305, CMS-306 (Deficiency Tracking } \\
\text { Management Plan) and CMELS-330 define } \\
\text { processes to regularly self assess operations, } \\
\text { facilities, activities and to report deficiencies. } \\
\text { Other feedback and improvement techniques } \\
\text { are defined in CMELS-330. Scheduled } \\
\text { inspections/self-assessments are used in } \\
\text { addition to employee reports and may initiate } \\
\text { ITS deficiencies. Suspect Counterfeit } \\
\text { Inspections are performed every three years. } \\
\text { ES\&H Manual, Document } 4.2, \text { "ES\&H Issues } \\
\text { and Deficiencies Management. }\end{array}$ \\
\hline $\begin{array}{l}\text { 8.2.6. Work } \\
\text { Authorization and } \\
\text { Documentation }\end{array}$ & $\begin{array}{l}\text { a) Written authorization should be } \\
\text { obtained for all shift activities } \\
\text { (including modifications or } \\
\text { maintenance) on equipment or } \\
\text { systems important to safety, that } \\
\text { affects operations, or that } \\
\text { changes control indications or } \\
\text { alarms. }\end{array}$ & Yes & FMC/PMC & $\begin{array}{l}\text { CMLS-405, Directorate Configuration } \\
\text { Management Plan. } \\
\text { Integrated Work Sheets. } \\
\text { ES\&H Manual, Document 2.1, "General Worker } \\
\text { Responsibilities and Integrated Safety } \\
\text { Management," and Document 2.2, "Managing } \\
\text { ES\&H for LLNL Work." }\end{array}$ \\
\hline
\end{tabular}




\section{Conduct of Operations Applicability Matrix for Low Hazard Facilities}

\begin{tabular}{|c|c|c|c|c|c|}
\hline $\begin{array}{l}\text { ES\&H MANUAL } \\
\text { DOCUMENT } 3.5 \\
\text { SECTION }\end{array}$ & & $\begin{array}{c}\text { REQUISITES FOR SECTION } \\
\text { ELEMENTS }\end{array}$ & $\begin{array}{l}\text { APPLICABLE } \\
\text { YES/NO }\end{array}$ & $\begin{array}{c}\text { RESPONSIBILITY } \\
\text { FOR } \\
\text { COMPLIANCE } \\
\text { FMC/PMC }^{1} \\
\end{array}$ & $\begin{array}{l}\text { COMMENTS AND/OR REFERENCE FOR } \\
\text { VERIFICATION OF COMPLIANCE }\end{array}$ \\
\hline $\begin{array}{l}\text { 8.2.7. Equipment } \\
\text { Post-Maintenance } \\
\text { Testing and Return to } \\
\text { Service }\end{array}$ & a) & $\begin{array}{l}\text { Establish post- } \\
\text { modification/maintenance testing } \\
\text { procedures for equipment or } \\
\text { systems important to safety. }\end{array}$ & Yes & FMC/PMC & $\begin{array}{l}\text { Plant Engineering maintains configuration } \\
\text { management of required building safety } \\
\text { systems and identifies post maintenance } \\
\text { testing requirements. Configuration } \\
\text { management on other building safety features } \\
\text { is the responsibility of the CMELS ADFM as } \\
\text { per CMLS-405. Configuration management on } \\
\text { activity-specific safety equipment (interlocks, } \\
\text { etc) is the responsibility of the RI. } \\
\text { Requirements for post } \\
\text { modification/maintenance testing for fume } \\
\text { hoods, glove boxes, and BSCs are identified in } \\
\text { ES\&H Manual Document } 12.4 \text { "Work } \\
\text { Enclosures and Local Exhaust Systems for } \\
\text { Toxic and Radioactive Materials." }\end{array}$ \\
\hline 8.2.8. Alarm Status & a) & $\begin{array}{l}\text { Ensure there is a clear } \\
\text { indication/understanding of alarm } \\
\text { status. }\end{array}$ & Yes & FMC/PMC & $\begin{array}{l}\text { CMELS FSPs discuss building alarms. Activity- } \\
\text { specific alarms are defined in applicable } \\
\text { IWS/SPs. LLNL ES\&H Manual; Document } 12.1 \\
\text { defines process for alarm systems. }\end{array}$ \\
\hline $\begin{array}{l}\text { 8.2.9. Temporary } \\
\text { Modification Control }\end{array}$ & a) & $\begin{array}{l}\text { Establish control for installing } \\
\text { temporary modifications to SSCs } \\
\text { under configuration management. }\end{array}$ & Yes & FMC/PMC & $\begin{array}{l}\text { Modifications to SSCs under CM are controlled } \\
\text { by the CM Plan specific to the individual CI. } \\
\text { ES\&H Manual, Document } 51.3 \text {. } \\
\text { ES\&H Manual, Document } 3.1 . \\
\text { ES\&H Manual, Document } 12.1 \text {. }\end{array}$ \\
\hline $\begin{array}{l}\text { 8.2.10. Distribution } \\
\text { and Control of } \\
\text { Equipment and } \\
\text { System Document }\end{array}$ & a) & $\begin{array}{l}\text { Establish system for document } \\
\text { control and distribution for } \\
\text { equipment or systems under } \\
\text { configuration management. }\end{array}$ & Yes & FMC/PMC & $\begin{array}{l}\text { Control and distribution of documents is } \\
\text { described in each CMP. }\end{array}$ \\
\hline
\end{tabular}




\section{Conduct of Operations Applicability Matrix for Low Hazard Facilities}

\begin{tabular}{|c|c|c|c|c|c|}
\hline $\begin{array}{l}\text { ES\&H MANUAL } \\
\text { DOCUMENT } 3.5 \\
\text { SECTION }\end{array}$ & & $\begin{array}{c}\text { REQUISITES FOR SECTION } \\
\text { ELEMENTS }\end{array}$ & $\begin{array}{l}\text { APPLICABLE } \\
\text { YES/NO }\end{array}$ & $\begin{array}{l}\text { RESPONSIBILITY } \\
\text { FOR } \\
\text { COMPLIANCE } \\
\text { FMC/PMC }^{1}\end{array}$ & $\begin{array}{l}\text { COMMENTS AND/OR REFERENCE FOR } \\
\text { VERIFICATION OF COMPLIANCE }\end{array}$ \\
\hline \multicolumn{6}{|l|}{$\begin{array}{l}\text { LOCKOUTS AND } \\
\text { TAGOUTS } \\
\text { SECTION } 9.0\end{array}$} \\
\hline $\begin{array}{l}\text { 9.2.1. Lockout/Tagout } \\
\text { Use }\end{array}$ & a) & $\begin{array}{l}\text { Work supervisors of LLNL and } \\
\text { subcontract workers shall satisfy } \\
\text { LLNL's lockout and tag program } \\
\text { requirements described in } \\
\text { Document } 12.6 \text {. }\end{array}$ & Yes & PMC & $\begin{array}{l}\text { Lockout and tagout is implemented through the } \\
\text { IWS process in accordance with Document } \\
12.6 \text { of the LLNL ES\&H Manual. }\end{array}$ \\
\hline \multirow[t]{2}{*}{$\begin{array}{l}\text { 9.2.2. Lockout and } \\
\text { Tagout } \\
\text { Implementation }\end{array}$} & a) & $\begin{array}{l}\text { Lockout/Tagout implementation } \\
\text { shall be in accordance with } \\
\text { Document } 12.6 .\end{array}$ & Yes & PMC & $\begin{array}{l}\text { Lockout and tagout is implemented through the } \\
\text { IWS process in accordance with Document } \\
12.6 \text { of the LLNL ES\&H Manual. }\end{array}$ \\
\hline & b) & $\begin{array}{l}\text { When appropriate, lockout and } \\
\text { tag requirements are incorporated } \\
\text { into (or referenced in) FSPs, } \\
\text { IWS/SPs, or SOPs. }\end{array}$ & Yes & PMC & $\begin{array}{l}\text { ES\&H Manual, Document 12.6, LLNL } \\
\text { Lockout/Tagout Program. }\end{array}$ \\
\hline $\begin{array}{l}\text { 9.2.3. Protective } \\
\text { Materials and } \\
\text { Hardware }\end{array}$ & a) & $\begin{array}{l}\text { Adequate protective materials and } \\
\text { hardware for lockout and tagout } \\
\text { are provided. }\end{array}$ & Yes & PMC & $\begin{array}{l}\text { ES\&H Manual, Document 12.6, LLNL } \\
\text { Lockout/Tagout Program. }\end{array}$ \\
\hline $\begin{array}{l}\text { 9.2.4. Lockout/Tagout } \\
\text { Program }\end{array}$ & a) & $\begin{array}{l}\text { A lockout/tagout program has } \\
\text { been established. }\end{array}$ & Yes & PMC & $\begin{array}{l}\text { Lockout and tagout is implemented through the } \\
\text { IWS process in accordance with Document } \\
12.6 \text { of the LLNL ES\&H Manual. }\end{array}$ \\
\hline $\begin{array}{l}\text { 9.2.5. Procedures for } \\
\text { Lockout/Tagout }\end{array}$ & a) & $\begin{array}{l}\text { Lockout/tagout procedures are } \\
\text { developed, documented, } \\
\text { validated, and utilized. }\end{array}$ & Yes & PMC & $\begin{array}{l}\text { ES\&H Manual, Document 12.6, LLNL } \\
\text { Lockout/Tagout Program. }\end{array}$ \\
\hline $\begin{array}{l}\text { 9.2.6. Application of } \\
\text { Lockout/Tagout }\end{array}$ & a) & $\begin{array}{l}\text { Established lockout/tagout } \\
\text { procedures cover the elements } \\
\text { and actions described in Section } \\
\text { 9.2.6 and Document 12.6. }\end{array}$ & Yes & PMC & $\begin{array}{l}\text { ES\&H Manual, Document 12.6, LLNL } \\
\text { Lockout/Tagout Program. }\end{array}$ \\
\hline
\end{tabular}




\section{Conduct of Operations Applicability Matrix for Low Hazard Facilities}

\begin{tabular}{|c|c|c|c|c|c|}
\hline $\begin{array}{l}\text { ES\&H MANUAL } \\
\text { DOCUMENT } 3.5 \\
\text { SECTION }\end{array}$ & & $\begin{array}{c}\text { REQUISITES FOR SECTION } \\
\text { ELEMENTS }\end{array}$ & $\begin{array}{l}\text { APPLICABLE } \\
\text { YES/NO }\end{array}$ & $\begin{array}{l}\text { RESPONSIBILITY } \\
\text { FOR } \\
\text { COMPLIANCE } \\
\text { FMC/PMC }^{1} \\
\end{array}$ & $\begin{array}{l}\text { COMMENTS AND/OR REFERENCE FOR } \\
\text { VERIFICATION OF COMPLIANCE }\end{array}$ \\
\hline $\begin{array}{l}\text { 9.2.7. Testing or } \\
\text { Positioning of } \\
\text { Equipment or } \\
\text { Components }\end{array}$ & a) & $\begin{array}{l}\text { For temporary removal of } \\
\text { Lockout/Tagout devices, follow } \\
\text { the actions described in Section } \\
9.2 .7 \text {. }\end{array}$ & Yes & PMC & $\begin{array}{l}\text { ES\&H Manual, Document 12.6, LLNL } \\
\text { Lockout/Tagout Program. }\end{array}$ \\
\hline $\begin{array}{l}\text { 9.2.8. Periodic } \\
\text { Inspections }\end{array}$ & a) & $\begin{array}{l}\text { Conduct periodic inspections to } \\
\text { determine adequacy of } \\
\text { lockout/tagout program, as } \\
\text { described in Document } 12.6 \text {. }\end{array}$ & Yes & PMC & $\begin{array}{l}\text { Lockout and tagout is implemented through the } \\
\text { IWS process in accordance with Document } \\
12.6 \text { of the LLNL ES\&H Manual. }\end{array}$ \\
\hline 9.2.9. Caution Tags & a) & $\begin{array}{l}\text { Use of caution tags should follow } \\
\text { protocol described in Section } \\
9.2 .9 \text { and as described in } \\
\text { Document } 12.6 \text {. }\end{array}$ & Yes & PMC & $\begin{array}{l}\text { ES\&H Manual, Document 12.6, LLNL } \\
\text { Lockout/Tagout Program. }\end{array}$ \\
\hline $\begin{array}{l}\text { 9.2.10. Training and } \\
\text { Communication }\end{array}$ & a) & $\begin{array}{l}\text { Personnel shall have training } \\
\text { consistent with Section 9.2.10. }\end{array}$ & Yes & PMC & $\begin{array}{l}\text { ES\&H Manual, Document 12.6, LLNL } \\
\text { Lockout/Tagout Program. }\end{array}$ \\
\hline $\begin{array}{l}\text { 9.2.11. Lockout or } \\
\text { Tagout } \\
\text { Implementation }\end{array}$ & a) & $\begin{array}{l}\text { Only authorized, qualified } \\
\text { personnel accomplish } \\
\text { lockout/tagout, as described in } \\
\text { Document } 12.6 \text {. }\end{array}$ & Yes & PMC & $\begin{array}{l}\text { ES\&H Manual, Document 12.6, LLNL } \\
\text { Lockout/Tagout Program. }\end{array}$ \\
\hline $\begin{array}{l}\text { 9.2.12. Notification of } \\
\text { Personnel }\end{array}$ & a) & $\begin{array}{l}\text { Personnel affected by the } \\
\text { lockout/tagout application or } \\
\text { removal are notified, as described } \\
\text { in Document } 12.6 \text {. }\end{array}$ & Yes & PMC & $\begin{array}{l}\text { ES\&H Manual, Document 12.6, LLNL } \\
\text { Lockout/Tagout Program. }\end{array}$ \\
\hline $\begin{array}{l}\text { 9.2.13. Outside } \\
\text { Contractors }\end{array}$ & a) & $\begin{array}{l}\text { Outside contractors adhere to } \\
\text { lockout/tagout procedures as } \\
\text { described in Document } 12.6 \text {. }\end{array}$ & Yes & PMC & $\begin{array}{l}\text { ES\&H Manual, Document 12.6, LLNL } \\
\text { Lockout/Tagout Program. }\end{array}$ \\
\hline $\begin{array}{l}\text { 9.2.14. Group } \\
\text { Lockouts or Tagouts }\end{array}$ & a) & $\begin{array}{l}\text { Adhere to group lockout/tagouts } \\
\text { procedures as described in } \\
\text { Document } 12.6 \text {. }\end{array}$ & Yes & PMC & $\begin{array}{l}\text { ES\&H Manual, Document 12.6, LLNL } \\
\text { Lockout/Tagout Program. }\end{array}$ \\
\hline
\end{tabular}




\section{Conduct of Operations Applicability Matrix for Low Hazard Facilities}

\begin{tabular}{|c|c|c|c|c|c|}
\hline $\begin{array}{l}\text { ES\&H MANUAL } \\
\text { DOCUMENT } 3.5 \\
\text { SECTION }\end{array}$ & & $\begin{array}{c}\text { REQUISITES FOR SECTION } \\
\text { ELEMENTS }\end{array}$ & $\begin{array}{l}\text { APPLICABLE } \\
\text { YES/NO }\end{array}$ & $\begin{array}{c}\text { RESPONSIBILITY } \\
\text { FOR } \\
\text { COMPLIANCE } \\
\text { FMC/PMC }^{1} \\
\end{array}$ & $\begin{array}{l}\text { COMMENTS AND/OR REFERENCE FOR } \\
\text { VERIFICATION OF COMPLIANCE }\end{array}$ \\
\hline $\begin{array}{l}\text { 9.2.15. Shift or } \\
\text { Personnel Changes }\end{array}$ & a) & $\begin{array}{l}\text { Adhere to procedures for } \\
\text { transferring locks and tags when } \\
\text { personnel or shifts change, as } \\
\text { described in Document } 12.6 \text {. }\end{array}$ & Yes & PMC & $\begin{array}{l}\text { ES\&H Manual, Document 12.6, LLNL } \\
\text { Lockout/Tagout Program. }\end{array}$ \\
\hline \multicolumn{6}{|l|}{$\begin{array}{l}\text { INDEPENDENT } \\
\text { VERIFICATION } \\
\text { SECTION } 10.0\end{array}$} \\
\hline $\begin{array}{l}\text { 10.2.1. Components } \\
\text { Requiring } \\
\text { Independent } \\
\text { Verification }\end{array}$ & & $\begin{array}{l}\text { Identify components/systems } \\
\text { requiring independent verification } \\
\text { whose improper positioning could } \\
\text { result in an impact to health, } \\
\text { safety, the environment, or } \\
\text { significant impact to programs. }\end{array}$ & Yes & FMC/PMC & $\begin{array}{l}\text { FSPs and IWSs are utilized to identify } \\
\text { Configuration Items and other } \\
\text { building/equipment safety features which } \\
\text { require independent verification of positioning. }\end{array}$ \\
\hline $\begin{array}{l}\text { 10.2.2. Occasions } \\
\text { Requiring } \\
\text { Independent } \\
\text { Verification }\end{array}$ & a) & $\begin{array}{l}\text { Ensure that independent } \\
\text { verification is conducted and } \\
\text { documented following the } \\
\text { guidance in Section 10.2.2. }\end{array}$ & Yes & FMC/PMC & $\begin{array}{l}\text { Prestart reviews verify that all systems are } \\
\text { functional and ready to go and documented as } \\
\text { part of the IWS process. }\end{array}$ \\
\hline $\begin{array}{l}\text { 10.2.3. Verification } \\
\text { Techniques }\end{array}$ & a) & $\begin{array}{l}\text { Ensure that verification } \\
\text { techniques are followed using the } \\
\text { guidance in Section 10.2.3. }\end{array}$ & Yes & FMC/PMC & $\begin{array}{l}\text { Verification follows the guidance in Section } \\
\text { 10.2.3. }\end{array}$ \\
\hline \multicolumn{6}{|l|}{$\begin{array}{l}\text { LOGKEEPING } \\
\text { SECTION } 11.0\end{array}$} \\
\hline $\begin{array}{l}\text { 11.2.1. Establishment } \\
\text { of Operating Logs }\end{array}$ & & $\begin{array}{l}\text { Identify operations, areas, or } \\
\text { equipment where formal record- } \\
\text { keeping is required, and assign } \\
\text { logbook-keeping responsibilities. }\end{array}$ & Yes & FMC/PMC & $\begin{array}{l}\text { Some programs require logbooks as part of their } \\
\text { QA program. These logbooks are managed per } \\
\text { the requirements in the respective ALQAP. } \\
\text { Logbooks are required for cranes, facility- } \\
\text { related oxygen deficiency monitors, forklift } \\
\text { operations, explosive inventories, radiation } \\
\text { area monitors, and emergency } \\
\text { eyewash/shower testing in CMELS Site } 200 \\
\text { facilities. }\end{array}$ \\
\hline
\end{tabular}




\section{Conduct of Operations Applicability Matrix for Low Hazard Facilities}

\begin{tabular}{|c|c|c|c|c|c|}
\hline $\begin{array}{l}\text { ES\&H MANUAL } \\
\text { DOCUMENT } 3.5 \\
\text { SECTION }\end{array}$ & & $\begin{array}{c}\text { REQUISITES FOR SECTION } \\
\text { ELEMENTS }\end{array}$ & $\begin{array}{l}\text { APPLICABLE } \\
\text { YES/NO }\end{array}$ & $\begin{array}{l}\text { RESPONSIBILITY } \\
\text { FOR } \\
\text { COMPLIANCE } \\
\text { FMC/PMC }^{1}\end{array}$ & $\begin{array}{l}\text { COMMENTS AND/OR REFERENCE FOR } \\
\text { VERIFICATION OF COMPLIANCE }\end{array}$ \\
\hline $\begin{array}{l}\text { 11.2.2. Timeliness of } \\
\text { Recordings }\end{array}$ & a) & $\begin{array}{l}\text { Ensure information is added in a } \\
\text { timely manner. }\end{array}$ & Yes & $\mathrm{FMC/PMC}$ & $\begin{array}{l}\text { Some programs require logbooks as part of thei } \\
\text { QA program. These logbooks are managed per } \\
\text { the requirements in the respective ALQAP. } \\
\text { Logbooks for cranes, oxygen deficiency } \\
\text { monitors, forklifts, and emergency } \\
\text { eyewash/showers, pressing, drying, and } \\
\text { radiography operations, and for quarterly } \\
\text { interlock checks will be completed in } \\
\text { accordance with the requirements listed in the } \\
\text { applicable ES\&H Manual sections and CMLS- } \\
305 \text {. }\end{array}$ \\
\hline $\begin{array}{l}\text { 11.2.3. Information to } \\
\text { be Recorded }\end{array}$ & a) & $\begin{array}{l}\text { Specify the type of information to } \\
\text { be entered in the logbook, using } \\
\text { the guidance in Section 11.2.3. }\end{array}$ & Yes & FMC/PMC & $\begin{array}{l}\text { Some programs require logbooks as part of their } \\
\text { QA program. These logbooks are managed per } \\
\text { the requirements in the respective ALQAP. } \\
\text { Logbooks for cranes, oxygen deficiency } \\
\text { monitors, forklifts, and emergency } \\
\text { eyewash/showers, pressing, drying, and } \\
\text { radiography operations, and for quarterly } \\
\text { interlock checks will be completed in } \\
\text { accordance with the requirements listed in the } \\
\text { applicable ES\&H Manual sections. }\end{array}$ \\
\hline 11.2.4. Legibility & a) & $\begin{array}{l}\text { Logbook entries should be made } \\
\text { in a legible and easily understood } \\
\text { manner. }\end{array}$ & Yes & FMC/PMC & $\begin{array}{l}\text { Some programs require logbooks as part of thei } \\
\text { QA program. These logbooks are managed per } \\
\text { the requirements in the respective ALQAP. }\end{array}$ \\
\hline 11.2.5. Corrections & a) & $\begin{array}{l}\text { Follow Section } 11.2 .5 \text { for } \\
\text { correcting erroneous entries. }\end{array}$ & Yes & FMC/PMC & $\begin{array}{l}\text { Some programs require logbooks as part of } \\
\text { their QA program. These logbooks are } \\
\text { managed per the requirements in the } \\
\text { respective ALQAP. }\end{array}$ \\
\hline
\end{tabular}




\section{Conduct of Operations Applicability Matrix for Low Hazard Facilities}

\begin{tabular}{|c|c|c|c|c|}
\hline $\begin{array}{c}\text { ES\&H MANUAL } \\
\text { DOCUMENT } 3.5 \\
\text { SECTION }\end{array}$ & $\begin{array}{c}\text { REQUISITES FOR SECTION } \\
\text { ELEMENTS }\end{array}$ & $\begin{array}{l}\text { APPLICABLE } \\
\text { YES/NO }\end{array}$ & $\begin{array}{c}\text { RESPONSIBILITY } \\
\text { FOR } \\
\text { COMPLIANCE } \\
\text { FMC/PMC }^{1}\end{array}$ & $\begin{array}{l}\text { COMMENTS AND/OR REFERENCE FOR } \\
\text { VERIFICATION OF COMPLIANCE }\end{array}$ \\
\hline 11.2.6. Log Review & $\begin{array}{l}\text { a) Regularly review the logbook for } \\
\text { conformance with logbook- } \\
\text { keeping requirements. }\end{array}$ & Yes & FMC/PMC & $\begin{array}{l}\text { Some programs require logbooks as part of their } \\
\text { QA program. These logbooks are managed per } \\
\text { the requirements in the respective ALQAP. } \\
\text { Work supervisors directly responsible for } \\
\text { logbook entries regarding cranes, oxygen } \\
\text { deficiency monitors, forklifts, eyewashes and } \\
\text { showers, pressing, drying, and radiography } \\
\text { operations, and for quarterly interlock check } \\
\text { work areas will regularly review logbooks in } \\
\text { their areas during informal self-assessments to } \\
\text { check for conformance with logbook-keeping } \\
\text { requirements and to spot trends that may } \\
\text { indicate degrading operations so that corrective } \\
\text { action can be taken before an emergency } \\
\text { occurs. }\end{array}$ \\
\hline $\begin{array}{l}\text { 11.2.7. Care and } \\
\text { Keeping of Logs }\end{array}$ & $\begin{array}{l}\text { a) Maintain logbooks in a retrievable } \\
\text { manner. }\end{array}$ & Yes & FMC/PMC & $\begin{array}{l}\text { Some programs require logbooks as part of their } \\
\text { QA program. These logbooks are managed per } \\
\text { the requirements in the respective ALQAP. } \\
\text { Logbooks for cranes, oxygen deficiency } \\
\text { monitors, forklifts, eyewashes and showers, } \\
\text { pressing, drying, and radiography operations, } \\
\text { and for quarterly interlock checks will be } \\
\text { protected from fire, water, or other types of } \\
\text { damage. } \\
\text { Completed logbooks will be retained in a } \\
\text { retrievable manner for time periods specified by } \\
\text { the facility manager or program. }\end{array}$ \\
\hline \multicolumn{5}{|l|}{$\begin{array}{l}\text { OPERATIONS } \\
\text { TURNOVER } \\
\text { SECTION } 12.0 \\
\end{array}$} \\
\hline $\begin{array}{l}\text { 12.2.1. Turnover } \\
\text { Checklists }\end{array}$ & $\begin{array}{l}\text { a) Identify personnel (by position), } \\
\text { that require a shift turnover } \\
\text { checklist. }\end{array}$ & No & NA & $\begin{array}{l}\text { Shifts are not utilized in CMELS S200 LHF } \\
\text { facilities. }\end{array}$ \\
\hline
\end{tabular}




\section{Conduct of Operations Applicability Matrix for Low Hazard Facilities}

\begin{tabular}{|c|c|c|c|c|c|}
\hline $\begin{array}{l}\text { ES\&H MANUAL } \\
\text { DOCUMENT } 3.5 \\
\text { SECTION }\end{array}$ & & $\begin{array}{c}\text { REQUISITES FOR SECTION } \\
\text { ELEMENTS }\end{array}$ & $\begin{array}{l}\text { APPLICABLE } \\
\text { YES/NO }\end{array}$ & $\begin{array}{c}\text { RESPONSIBILITY } \\
\text { FOR } \\
\text { COMPLIANCE } \\
\text { FMC/PMC }^{1} \\
\end{array}$ & $\begin{array}{l}\text { COMMENTS AND/OR REFERENCE FOR } \\
\text { VERIFICATION OF COMPLIANCE }\end{array}$ \\
\hline & b) & $\begin{array}{l}\text { Develop shift turnover } \\
\text { checklist(s). }\end{array}$ & No & NA & $\begin{array}{l}\text { Shifts are not utilized in CMELS S200 LHF } \\
\text { facilities. }\end{array}$ \\
\hline $\begin{array}{l}\text { 12.2.2. Document } \\
\text { Review }\end{array}$ & a) & $\begin{array}{l}\text { Oncoming operators and } \\
\text { supervisors review documents } \\
\text { specified on their checklists. }\end{array}$ & No & NA & $\begin{array}{l}\text { Shifts are not utilized in CMELS S200 LHF } \\
\text { facilities. }\end{array}$ \\
\hline $\begin{array}{l}\text { 12.2.3. Control Panel } \\
\text { Walkdown }\end{array}$ & a) & $\begin{array}{l}\text { Conduct control panel walkdowns } \\
\text { as appropriate. }\end{array}$ & No & NA & $\begin{array}{l}\text { Shifts are not utilized in CMELS S200 LHF } \\
\text { facilities. }\end{array}$ \\
\hline $\begin{array}{l}\text { 12.2.4. Discussion } \\
\text { and Exchange of } \\
\text { Responsibility }\end{array}$ & a) & $\begin{array}{l}\text { Conduct discussion and exchange } \\
\text { of responsibility at shift change. }\end{array}$ & No & NA & $\begin{array}{l}\text { Shifts are not utilized in CMELS S200 LHF } \\
\text { facilities. }\end{array}$ \\
\hline $\begin{array}{l}\text { 12.2.5. Shift Crew } \\
\text { Briefing }\end{array}$ & a) & $\begin{array}{l}\text { Operations supervisors conduct } \\
\text { crew briefing as required. }\end{array}$ & No & NA & $\begin{array}{l}\text { Shifts are not utilized in CMELS S200 LHF } \\
\text { facilities. }\end{array}$ \\
\hline $\begin{array}{l}\text { 12.2.6. Reliefs } \\
\text { Occurring During the } \\
\text { Shift }\end{array}$ & a) & $\begin{array}{l}\text { Specify and document shift } \\
\text { turnover responsibilities. }\end{array}$ & No & NA & $\begin{array}{l}\text { Shifts are not utilized in CMELS S200 LHF } \\
\text { facilities. }\end{array}$ \\
\hline \multicolumn{6}{|l|}{$\begin{array}{c}\text { OPERATIONS } \\
\text { ASPECTS OF } \\
\text { FACILITY } \\
\text { CHEMISTRY AND } \\
\text { UNIQUE } \\
\text { PROCESSES } \\
\text { SECTION } 13.0 \\
\end{array}$} \\
\hline $\begin{array}{l}\text { 13.2.1. Operator } \\
\text { Responsibilities }\end{array}$ & a) & $\begin{array}{l}\text { Identify the samples requiring } \\
\text { analysis and analysis to be } \\
\text { performed, and define the range } \\
\text { of acceptable results. }\end{array}$ & No & NA & $\begin{array}{l}\text { There are no routine programmatic or facility- } \\
\text { related sampling and analyzing efforts of } \\
\text { operating parameters. Some institutionally } \\
\text { required chemical analysis to protect ES\&H is } \\
\text { performed by EPD and the ES\&H Team. }\end{array}$ \\
\hline
\end{tabular}




\section{Conduct of Operations Applicability Matrix for Low Hazard Facilities}

\begin{tabular}{|c|c|c|c|c|c|}
\hline $\begin{array}{l}\text { ES\&H MANUAL } \\
\text { DOCUMENT } 3.5 \\
\text { SECTION } \\
\end{array}$ & & $\begin{array}{c}\text { REQUISITES FOR SECTION } \\
\text { ELEMENTS }\end{array}$ & $\begin{array}{l}\text { APPLICABLE } \\
\text { YES/NO }\end{array}$ & $\begin{array}{c}\text { RESPONSIBILITY } \\
\text { FOR } \\
\text { COMPLIANCE } \\
\text { FMC/PMC }^{1} \\
\end{array}$ & $\begin{array}{l}\text { COMMENTS AND/OR REFERENCE FOR } \\
\text { VERIFICATION OF COMPLIANCE }\end{array}$ \\
\hline & b) & $\begin{array}{l}\text { Ensure that workers involved in } \\
\text { sampling and analyses } \\
\text { understand their responsibilities. }\end{array}$ & No & NA & $\begin{array}{l}\text { There are no routine programmatic or facility- } \\
\text { related sampling and analyzing efforts of } \\
\text { operating parameters. Some institutionally } \\
\text { required chemical analysis to protect ES\&H is } \\
\text { performed by EPD and the ES\&H Team. }\end{array}$ \\
\hline $\begin{array}{l}\text { 13.2.2. Operator } \\
\text { Knowledge }\end{array}$ & a) & $\begin{array}{l}\text { Ensure workers have the } \\
\text { necessary training and equipment } \\
\text { to carry out their specified tasks. }\end{array}$ & No & NA & $\begin{array}{l}\text { There are no routine programmatic or facility- } \\
\text { related sampling and analyzing efforts of } \\
\text { operating parameters. Some institutionally } \\
\text { required chemical analysis to protect ES\&H is } \\
\text { performed by EPD and the ES\&H Team. }\end{array}$ \\
\hline $\begin{array}{l}\text { 13.2.3. Operator } \\
\text { Response to Process } \\
\text { Problems }\end{array}$ & a) & $\begin{array}{l}\text { Respond to out-of-range results or } \\
\text { process parameters. }\end{array}$ & No & NA & $\begin{array}{l}\text { There are no routine programmatic or facility- } \\
\text { related sampling and analyzing efforts of } \\
\text { operating parameters. Some institutionally } \\
\text { required chemical analysis to protect ES\&H is } \\
\text { performed by EPD and the ES\&H Team. }\end{array}$ \\
\hline $\begin{array}{l}13.2 .4 \text {. } \\
\text { Communication } \\
\text { Between Operations } \\
\text { and Process } \\
\text { Personnel }\end{array}$ & a) & $\begin{array}{l}\text { Maintain communication between } \\
\text { operations and process } \\
\text { personnel. }\end{array}$ & No & NA & $\begin{array}{l}\text { There are no routine programmatic or facility- } \\
\text { related sampling and analyzing efforts of } \\
\text { operating parameters. Some institutionally } \\
\text { required chemical analysis to protect ES\&H is } \\
\text { performed by EPD and the ES\&H Team. }\end{array}$ \\
\hline \multicolumn{6}{|l|}{$\begin{array}{l}\text { REQUIRED } \\
\text { READING } \\
\text { SECTION } 14.0 \\
\end{array}$} \\
\hline 14.2.1. File Index & & $\begin{array}{l}\text { Identify documents to be included } \\
\text { in each facility's required reading } \\
\text { program. }\end{array}$ & Yes & FMC/PMC & $\begin{array}{l}\text { FSPs are the only facility-level document } \\
\text { identified as required reading; all residents } \\
\text { must read the sections applicable to their work } \\
\text { Workers are required to read the IWSs for their } \\
\text { work. Each IWS identifies any supplemental } \\
\text { required reading for each activity (e.g., SP, } \\
\text { Hazard Assessment and Control, Engineering } \\
\text { Safety Note, etc.) }\end{array}$ \\
\hline
\end{tabular}




\section{Conduct of Operations Applicability Matrix for Low Hazard Facilities}

\begin{tabular}{|c|c|c|c|c|c|}
\hline $\begin{array}{c}\text { ES\&H MANUAL } \\
\text { DOCUMENT } 3.5 \\
\text { SECTION } \\
\end{array}$ & & $\begin{array}{c}\text { REQUISITES FOR SECTION } \\
\text { ELEMENTS }\end{array}$ & $\begin{array}{l}\text { APPLICABLE } \\
\text { YES/NO }\end{array}$ & $\begin{array}{c}\text { RESPONSIBILITY } \\
\text { FOR } \\
\text { COMPLIANCE } \\
\text { FMC/PMC }^{1} \\
\end{array}$ & $\begin{array}{l}\text { COMMENTS AND/OR REFERENCE FOR } \\
\text { VERIFICATION OF COMPLIANCE }\end{array}$ \\
\hline \multirow[t]{2}{*}{$\begin{array}{l}\text { 14.2.2. Reading } \\
\text { Assignments }\end{array}$} & a) & $\begin{array}{l}\text { Identify which documents must be } \\
\text { read by individuals (by position). }\end{array}$ & Yes & FMC/PMC & $\begin{array}{l}\text { FSPs are the only facility-level document } \\
\text { identified as required reading. Workers are } \\
\text { required to read the IWSs for their work. Each } \\
\text { IWS identifies any supplemental required } \\
\text { reading for each activity (e.g., SP, Hazard } \\
\text { Assessment). }\end{array}$ \\
\hline & b) & $\begin{array}{l}\text { Required reading documents } \\
\text { should be available in the facility } \\
\text { or in the program area. }\end{array}$ & Yes & $\mathrm{FMC} / \mathrm{PMC}$ & $\begin{array}{l}\text { Documents identified in the IWSs are either } \\
\text { uploaded to the IWS or are maintained by the R } \\
\text { for that activity. Facility specific documents are } \\
\text { maintained at: } \\
\text { http://sodium.IInl.gov/cmels/ }\end{array}$ \\
\hline $\begin{array}{l}\text { 14.2.3. Required } \\
\text { Dates for Completion } \\
\text { of Reading }\end{array}$ & a) & $\begin{array}{l}\text { Designate completion dates for } \\
\text { required reading. }\end{array}$ & Yes & $\mathrm{FMC} / \mathrm{PMC}$ & $\begin{array}{l}\text { Formal FSP training is provided by CMELS, and } \\
\text { completion is documented in LTRAIN. } \\
\text { Each RI verifies that their employees complete } \\
\text { the required reading for their activity. Each } \\
\text { employee will electronically sign the IWSs for } \\
\text { any IWS/SPs under which they work. }\end{array}$ \\
\hline $\begin{array}{l}\text { 14.2.4. } \\
\text { Documentation }\end{array}$ & a) & $\begin{array}{l}\text { Provide a system for documenting } \\
\text { that workers have completed the } \\
\text { required reading. }\end{array}$ & Yes & $\mathrm{FMC} / \mathrm{PMC}$ & $\begin{array}{l}\text { Formal FSP training is provided by CMELS, and } \\
\text { completion is documented in LTRAIN. } \\
\text { Each RI verifies that their employees complete } \\
\text { the required reading for their activity. Each } \\
\text { employee will electronically sign the IWSs for } \\
\text { any IWS/SPs under which they work. }\end{array}$ \\
\hline 14.2.5. Review & a) & $\begin{array}{l}\text { Regularly review and update the } \\
\text { required reading list. }\end{array}$ & Yes & $\mathrm{FMC} / \mathrm{PMC}$ & $\begin{array}{l}\text { FSPs are reviewed and re-issued at least every } \\
\text { three years. }\end{array}$ \\
\hline
\end{tabular}




\section{Conduct of Operations Applicability Matrix for Low Hazard Facilities}

\begin{tabular}{|c|c|c|c|c|c|}
\hline $\begin{array}{l}\text { ES\&H MANUAL } \\
\text { DOCUMENT } 3.5 \\
\quad \text { SECTION }\end{array}$ & & $\begin{array}{l}\text { REQUISITES FOR SECTION } \\
\text { ELEMENTS }\end{array}$ & $\begin{array}{l}\text { APPLICABLE } \\
\text { YES/NO }\end{array}$ & $\begin{array}{l}\text { RESPONSIBILITY } \\
\text { FOR } \\
\text { COMPLIANCE } \\
\text { FMC/PMC }\end{array}$ & $\begin{array}{l}\text { COMMENTS AND/OR REFERENCE FOR } \\
\text { VERIFICATION OF COMPLIANCE }\end{array}$ \\
\hline \multicolumn{6}{|l|}{$\begin{array}{l}\text { TIMELY ORDERS } \\
\text { TO OPERATORS } \\
\text { SECTION } 15.0 \\
\end{array}$} \\
\hline \multirow[t]{2}{*}{$\begin{array}{l}\text { 15.2.1. Content and } \\
\text { Format }\end{array}$} & & $\begin{array}{l}\text { Describe how special instructions } \\
\text { (short and long term) will be } \\
\text { developed for communication to } \\
\text { workers/operators. }\end{array}$ & Yes & FMC/PMC & $\begin{array}{l}\text { Instructions for work activities are identified } \\
\text { through the IWS for programmatic work } \\
\text { activities. Facility instructions (such as shut } \\
\text { down of hoods or retention tanks) are } \\
\text { communicated by the Facility Point of Contact } \\
\text { to building residents through e-mail, building } \\
\text { announcements, paper postings, etc. Special } \\
\text { instructions to programmatic workers are } \\
\text { communicated directly by managers and } \\
\text { supervisors via e-mail, telephone, and/or } \\
\text { personal communication. }\end{array}$ \\
\hline & b) & $\begin{array}{l}\text { Document how orders that are } \\
\text { issued to supplement operating } \\
\text { procedures will be incorporated. }\end{array}$ & Yes & FMC/PMC & $\begin{array}{l}\text { Instructions for work activities are identified } \\
\text { through the IWS for programmatic work } \\
\text { activities. Facility instructions (such as shut } \\
\text { down of hoods or retention tanks) are } \\
\text { communicated by the Facility Point of Contact } \\
\text { to building residents through e-mail, building } \\
\text { announcements, paper postings, etc. Special } \\
\text { instructions to programmatic workers are } \\
\text { communicated directly by managers and } \\
\text { supervisors via e-mail, telephone, and/or } \\
\text { personal communication. }\end{array}$ \\
\hline \multirow[t]{2}{*}{$\begin{array}{l}\text { 15.2.2. Issuing, } \\
\text { Segregating, and } \\
\text { Reviewing Orders }\end{array}$} & & $\begin{array}{l}\text { Describe process for issuing Shift } \\
\text { Orders/Instructions to } \\
\text { workers/operators. }\end{array}$ & Yes & FMC/PMC & $\begin{array}{l}\text { Instructions are issued through e-mail, building } \\
\text { announcements, phone calls, alpha-numeric } \\
\text { pagers, paper postings, in-person verbally, etc. }\end{array}$ \\
\hline & & $\begin{array}{l}\text { Describe process for issuing } \\
\text { Standing Orders/lnstructions to } \\
\text { workers/operators. }\end{array}$ & Yes & FMC/PMC & $\begin{array}{l}\text { Standing orders are documented and issued in } \\
\text { the work authorization documents (IWS's, } \\
\text { PWS's, Service Work Authorization docs, etc). }\end{array}$ \\
\hline
\end{tabular}




\section{Conduct of Operations Applicability Matrix for Low Hazard Facilities}

\begin{tabular}{|c|c|c|c|c|c|}
\hline $\begin{array}{l}\text { ES\&H MANUAL } \\
\text { DOCUMENT } 3.5 \\
\text { SECTION }\end{array}$ & & $\begin{array}{c}\text { REQUISITES FOR SECTION } \\
\text { ELEMENTS }\end{array}$ & $\begin{array}{l}\text { APPLICABLE } \\
\text { YES/NO }\end{array}$ & $\begin{array}{c}\text { RESPONSIBILITY } \\
\text { FOR } \\
\text { COMPLIANCE } \\
\text { FMC/PMC }^{1} \\
\end{array}$ & $\begin{array}{l}\text { COMMENTS AND/OR REFERENCE FOR } \\
\text { VERIFICATION OF COMPLIANCE }\end{array}$ \\
\hline $\begin{array}{l}\text { 15.2.3. Removal of } \\
\text { Orders }\end{array}$ & a) & $\begin{array}{l}\text { Remove/cancel expired or } \\
\text { outdated orders. }\end{array}$ & Yes & FMC/PMC & $\begin{array}{l}\text { Cancellation of standing orders are } \\
\text { documented and issued in the work } \\
\text { authorization documents (IWS's, PWS's, } \\
\text { Service Work Authorization docs, etc). } \\
\text { Cancellation of shift orders is made through e- } \\
\text { mail, building announcements, phone calls, } \\
\text { alpha-numeric pagers, paper postings, in- } \\
\text { person verbally, etc. }\end{array}$ \\
\hline \multicolumn{6}{|l|}{$\begin{array}{l}\text { OPERATIONS } \\
\text { PROCEDURES } \\
\text { SECTION } 16.0\end{array}$} \\
\hline $\begin{array}{l}\text { 16.2.1. Procedure } \\
\text { Development }\end{array}$ & a) & $\begin{array}{l}\text { Identify equipment/operations that } \\
\text { require operating procedures. }\end{array}$ & Yes & FMC/PMC & $\begin{array}{l}\text { The need for operating procedures in } \\
\text { accordance with Document } 3.4 \text { of the ES\&H } \\
\text { Manual is determined through the IWS } \\
\text { process. Equipment/systems that need } \\
\text { operating procedures from a programmatic } \\
\text { impact standpoint are managed in accordance } \\
\text { with CMLS-901 (Quality Assurance Plan). } \\
\text { Instructions for equipment operation can also } \\
\text { be identified through the IWS for programmatic } \\
\text { and facility equipment. }\end{array}$ \\
\hline $\begin{array}{l}\text { 16.2.2. Procedure } \\
\text { Content }\end{array}$ & a) & $\begin{array}{l}\text { Ensure that the content of } \\
\text { operating procedures conforms to } \\
\text { prescribed guidelines }\end{array}$ & Yes & FMC/PMC & $\begin{array}{l}\text { Document } 3.4 \text { of the ES\&H Manual defines } \\
\text { requirements for operating procedures. } \\
\text { CMELS-904 (Control of Unclassified } \\
\text { Management Documents) defines CMELS } \\
\text { requirements for work procedures. }\end{array}$ \\
\hline $\begin{array}{l}\text { 16.2.3. Procedure } \\
\text { Changes and } \\
\text { Revisions }\end{array}$ & a) & $\begin{array}{l}\text { Specify a method for initiating } \\
\text { temporary and permanent } \\
\text { changes to operating procedures }\end{array}$ & Yes & FMC/PMC & $\begin{array}{l}\text { Document } 3.4 \text { of the ES\&H Manual defines } \\
\text { requirements for operating procedures. } \\
\text { CMELS-904 defines CMELS requirements for } \\
\text { work procedures. }\end{array}$ \\
\hline $\begin{array}{l}\text { 16.2.4. Procedure } \\
\text { Approval }\end{array}$ & & $\begin{array}{l}\text { Identify procedure approval } \\
\text { protocol. }\end{array}$ & Yes & FMC/PMC & $\begin{array}{l}\text { Document } 3.4 \text { of the ES\&H Manual defines } \\
\text { requirements for operating procedures. } \\
\text { CMELS-904 defines CMELS requirements for } \\
\text { work procedures. }\end{array}$ \\
\hline
\end{tabular}




\section{Conduct of Operations Applicability Matrix for Low Hazard Facilities}

\begin{tabular}{|c|c|c|c|c|c|}
\hline $\begin{array}{l}\text { ES\&H MANUAL } \\
\text { DOCUMENT } 3.5 \\
\text { SECTION }\end{array}$ & & $\begin{array}{c}\text { REQUISITES FOR SECTION } \\
\text { ELEMENTS }\end{array}$ & $\begin{array}{l}\text { APPLICABLE } \\
\text { YES/NO }\end{array}$ & $\begin{array}{c}\text { RESPONSIBILITY } \\
\text { FOR } \\
\text { COMPLIANCE } \\
\text { FMC/PMC }^{1} \\
\end{array}$ & $\begin{array}{l}\text { COMMENTS AND/OR REFERENCE FOR } \\
\text { VERIFICATION OF COMPLIANCE }\end{array}$ \\
\hline \multirow[t]{3}{*}{$\begin{array}{l}\text { 16.2.5. Procedure } \\
\text { Review }\end{array}$} & a) & $\begin{array}{l}\text { Identify procedure review } \\
\text { protocol. }\end{array}$ & Yes & FMC/PMC & $\begin{array}{l}\text { Document } 3.4 \text { of the ES\&H Manual defines } \\
\text { requirements for operating procedures. } \\
\text { CMELS-904 defines CMELS requirements for } \\
\text { work procedures. }\end{array}$ \\
\hline & b) & $\begin{array}{l}\text { Ensure that new operating } \\
\text { procedures and those undergoing } \\
\text { major revision are verified for } \\
\text { correctness and operationally } \\
\text { tested prior to final approval and } \\
\text { use. }\end{array}$ & Yes & FMC/PMC & $\begin{array}{l}\text { Document } 3.4 \text { of the ES\&H Manual defines } \\
\text { requirements for operating procedures. } \\
\text { CMELS-904 defines CMELS requirements for } \\
\text { work procedures. }\end{array}$ \\
\hline & c) & $\begin{array}{l}\text { Review operating procedures to } \\
\text { ensure they are kept current. }\end{array}$ & Yes & FMC/PMC & $\begin{array}{l}\text { Document } 3.4 \text { of the ES\&H Manual defines } \\
\text { requirements for operating procedures. In } \\
\text { accordance with the ES\&H Manual, FSPs are } \\
\text { updated at least every three years (the sections } \\
\text { applying to explosives safety controls are } \\
\text { reviewed annually) and IWS/SPs are reviewed } \\
\text { at least annually. CMELS-904 defines CMELS } \\
\text { requirements for work procedures. }\end{array}$ \\
\hline $\begin{array}{l}\text { 16.2.6. Procedure } \\
\text { Availability }\end{array}$ & a) & $\begin{array}{l}\text { Copies of applicable operating } \\
\text { procedures are available and } \\
\text { controlled. }\end{array}$ & Yes & FMC/PMC & $\begin{array}{l}\text { Document } 3.4 \text { of the ES\&H Manual defines } \\
\text { requirements for operating procedures. CMELS- } \\
904 \text { defines CMELS requirements for work } \\
\text { procedures. } \\
\text { RIs routinely upload current copies of relevant } \\
\text { procedures and safety plans to their IWSs. } \\
\text { Facility-specific documents are maintained at: } \\
\text { http://sodium.IInl.gov/cmels/ }\end{array}$ \\
\hline
\end{tabular}




\section{Conduct of Operations Applicability Matrix for Low Hazard Facilities}

\begin{tabular}{|c|c|c|c|c|}
\hline $\begin{array}{l}\text { ES\&H MANUAL } \\
\text { DOCUMENT } 3.5 \\
\quad \text { SECTION }\end{array}$ & $\begin{array}{c}\text { REQUISITES FOR SECTION } \\
\text { ELEMENTS }\end{array}$ & $\begin{array}{l}\text { APPLICABLE } \\
\text { YES/NO }\end{array}$ & $\begin{array}{c}\text { RESPONSIBILITY } \\
\text { FOR } \\
\text { COMPLIANCE } \\
\text { FMC/PMC }^{1}\end{array}$ & $\begin{array}{l}\text { COMMENTS AND/OR REFERENCE FOR } \\
\text { VERIFICATION OF COMPLIANCE }\end{array}$ \\
\hline $\begin{array}{l}\text { 16.2.7. Procedure } \\
\text { Use }\end{array}$ & $\begin{array}{l}\text { a) Operators/Workers should be } \\
\text { instructed in the use of } \\
\text { procedures. }\end{array}$ & Yes & FMC/PMC & $\begin{array}{l}\text { Document } 3.4 \text { of the ES\&H Manual defines } \\
\text { requirements for operating procedures. CMELS- } \\
904 \text { defines CMELS requirements for work } \\
\text { procedures. } \\
\text { RIs routinely upload current copies of relevant } \\
\text { procedures and safety plans to their IWSs. } \\
\text { Facility-specific documents are maintained at: } \\
\text { http://sodium.IInl.gov/cmels/ } \\
\text { Activity Responsible Individuals are responsible } \\
\text { to ensuring that workers are trained in the } \\
\text { proper use of applicable procedures. }\end{array}$ \\
\hline \multicolumn{5}{|l|}{$\begin{array}{l}\text { OPERATOR AID } \\
\text { POSTINGS } \\
\text { SECTION } 17.0\end{array}$} \\
\hline $\begin{array}{l}\text { 17.2.1. Operator Aid } \\
\text { Development }\end{array}$ & $\begin{array}{l}\text { a) Identify and maintain operator } \\
\text { aids that must be controlled. }\end{array}$ & No & NA & $\begin{array}{l}\text { Operator aids whose accuracy is critical to } \\
\text { operating a system or piece of equipment so } \\
\text { that it does not produce a significant impact to } \\
\text { health, safety, the environment, or programs } \\
\text { are not used in these facilities. }\end{array}$ \\
\hline 17.2.2. Approval & $\begin{array}{l}\text { a) Identify the individual responsible } \\
\text { for approving operator aids. }\end{array}$ & No & NA & $\begin{array}{l}\text { Operator aids whose accuracy is critical to } \\
\text { operating a system or piece of equipment so } \\
\text { that it does not produce a significant impact to } \\
\text { health, safety, the environment, or programs } \\
\text { are not used in these facilities. }\end{array}$ \\
\hline 17.2.3. Posting & $\begin{array}{l}\text { a) Ensure that operator aids are } \\
\text { posted so that they do not } \\
\text { obscure or interfere with } \\
\text { instruments or controls. }\end{array}$ & No & NA & $\begin{array}{l}\text { Operator aids whose accuracy is critical to } \\
\text { operating a system or piece of equipment so } \\
\text { that it does not produce a significant impact to } \\
\text { health, safety, the environment, or programs } \\
\text { are not used in these facilities. }\end{array}$ \\
\hline
\end{tabular}




\section{Conduct of Operations Applicability Matrix for Low Hazard Facilities}

\begin{tabular}{|c|c|c|c|c|c|}
\hline $\begin{array}{l}\text { ES\&H MANUAL } \\
\text { DOCUMENT } 3.5 \\
\quad \text { SECTION }\end{array}$ & & $\begin{array}{c}\text { REQUISITES FOR SECTION } \\
\text { ELEMENTS }\end{array}$ & $\begin{array}{l}\text { APPLICABLE } \\
\text { YES/NO }\end{array}$ & $\begin{array}{c}\text { RESPONSIBILITY } \\
\text { FOR } \\
\text { COMPLIANCE } \\
\text { FMC/PMC }^{1} \\
\end{array}$ & $\begin{array}{l}\text { COMMENTS AND/OR REFERENCE FOR } \\
\text { VERIFICATION OF COMPLIANCE }\end{array}$ \\
\hline & b) & $\begin{array}{l}\text { Ensure that operator aids are } \\
\text { legible and posted as close as } \\
\text { practical to the system or } \\
\text { equipment with which they are } \\
\text { associated. }\end{array}$ & No & NA & $\begin{array}{l}\text { Operator aids whose accuracy is critical to } \\
\text { operating a system or piece of equipment so } \\
\text { that it does not produce a significant impact to } \\
\text { health, safety, the environment, or programs } \\
\text { are not used in these facilities. }\end{array}$ \\
\hline $\begin{array}{l}\text { 17.2.4. Use of } \\
\text { Operator Aids }\end{array}$ & a) & $\begin{array}{l}\text { Operator aid developers and } \\
\text { users should understand their } \\
\text { purpose (e.g. convenience, not } \\
\text { requirement, supplement to } \\
\text { approved procedures) and } \\
\text { limitation (not used in lieu of } \\
\text { approved procedure) }\end{array}$ & No & NA & $\begin{array}{l}\text { Operator aids whose accuracy is critical to } \\
\text { operating a system or piece of equipment so } \\
\text { that it does not produce a significant impact to } \\
\text { health, safety, the environment, or programs } \\
\text { are not used in these facilities. }\end{array}$ \\
\hline $\begin{array}{l}\text { 17.2.5. } \\
\text { Documentation }\end{array}$ & a) & $\begin{array}{l}\text { Maintain a listing of all approved } \\
\text { operator aids. }\end{array}$ & No & NA & $\begin{array}{l}\text { Operator aids whose accuracy is critical to } \\
\text { operating a system or piece of equipment so } \\
\text { that it does not produce a significant impact to } \\
\text { health, safety, the environment, or programs } \\
\text { are not used in these facilities. }\end{array}$ \\
\hline 17.2.6. Review & a) & $\begin{array}{l}\text { Ensure that operator aids are } \\
\text { regularly reviewed to verify they } \\
\text { are current and appropriate. }\end{array}$ & No & NA & $\begin{array}{l}\text { Operator aids whose accuracy is critical to } \\
\text { operating a system or piece of equipment so } \\
\text { that it does not produce a significant impact to } \\
\text { health, safety, the environment, or programs } \\
\text { are not used in these facilities. }\end{array}$ \\
\hline \multicolumn{6}{|l|}{$\begin{array}{l}\text { EQUIPMENT AND } \\
\text { PIPING LABELING } \\
\text { SECTION } 18.0\end{array}$} \\
\hline $\begin{array}{l}\text { 18.2.1. Components } \\
\text { Requiring Labeling }\end{array}$ & & $\begin{array}{l}\text { Identify and maintain a listing of } \\
\text { equipment and piping that should } \\
\text { be labeled in accordance with } \\
\text { section 18.2.1. }\end{array}$ & Yes & FMC/PMC & $\begin{array}{l}\text { Plant Engineering Standards PEL-M- } \\
\text { 11009, (Rev. G or latest revision) for } \\
\text { equipment, and PEL-M-02650, (Rev. A or } \\
\text { latest revision) for piping and valve } \\
\text { identification. }\end{array}$ \\
\hline
\end{tabular}




\section{Conduct of Operations Applicability Matrix for Low Hazard Facilities}

\begin{tabular}{|c|c|c|c|c|c|}
\hline $\begin{array}{l}\text { ES\&H MANUAL } \\
\text { DOCUMENT } 3.5 \\
\text { SECTION }\end{array}$ & & $\begin{array}{c}\text { REQUISITES FOR SECTION } \\
\text { ELEMENTS }\end{array}$ & $\begin{array}{l}\text { APPLICABLE } \\
\text { YES/NO }\end{array}$ & $\begin{array}{c}\text { RESPONSIBILITY } \\
\text { FOR } \\
\text { COMPLIANCE } \\
\text { FMC/PMC }\end{array}$ & $\begin{array}{l}\text { COMMENTS AND/OR REFERENCE FOR } \\
\text { VERIFICATION OF COMPLIANCE }\end{array}$ \\
\hline \multirow[t]{2}{*}{$\begin{array}{l}\text { 18.2.2. Label } \\
\text { Information }\end{array}$} & a) & $\begin{array}{l}\text { Use the Plant Engineering } \\
\text { Department standards for label } \\
\text { requirements and abbreviations. }\end{array}$ & Yes & FMC/PMC & $\begin{array}{l}\text { Plant Engineering Standards PEL-M- } \\
\text { 11009, (Rev. G or latest revision) for } \\
\text { equipment, and PEL-M-02650, (Rev. A or } \\
\text { latest revision) for piping and valve } \\
\text { identification. }\end{array}$ \\
\hline & b) & $\begin{array}{l}\text { Ensure workers are trained or } \\
\text { instructed before performing } \\
\text { maintenance on labeled } \\
\text { equipment. }\end{array}$ & Yes & FMC/PMC & $\begin{array}{l}\text { Plant Engineering Standards PEL-M- } \\
11009, \text { (Rev. G or latest revision) for } \\
\text { equipment, and PEL-M-02650, (Rev. A or } \\
\text { latest revision) for piping and valve } \\
\text { identification. }\end{array}$ \\
\hline $\begin{array}{l}\text { 18.2.3. Label } \\
\text { Placement }\end{array}$ & a) & $\begin{array}{l}\text { Use Plant Engineering Standards } \\
\text { PEL-M-11009, (Rev. G or latest } \\
\text { revision) (for equipment) and } \\
\text { PEL-M-02650, (Rev. A or latest } \\
\text { revision) (for piping and valve } \\
\text { identification) for label placement. }\end{array}$ & Yes & FMC/PMC & $\begin{array}{l}\text { Plant Engineering Standards PEL-M- } \\
\text { 11009, (Rev. G or latest revision) for } \\
\text { equipment, and PEL-M-02650, (Rev. A or } \\
\text { latest revision) for piping and valve } \\
\text { identification. }\end{array}$ \\
\hline $\begin{array}{l}\text { 18.2.4. Replacing } \\
\text { Labels }\end{array}$ & a) & $\begin{array}{l}\text { Ensure processes (e.g. post- } \\
\text { maintenance tests, lineup sheets, } \\
\text { etc.) include provisions to check } \\
\text { for labels that are missing, } \\
\text { damaged or have incorrect } \\
\text { information and new labels are } \\
\text { promptly provided. }\end{array}$ & Yes & FMC/PMC & $\begin{array}{l}\text { Plant Engineering Standards PEL-M- } \\
11009, \text { (Rev. G or latest revision) for } \\
\text { equipment, and PEL-M-02650, (Rev. A or } \\
\text { latest revision) for piping and valve } \\
\text { identification. }\end{array}$ \\
\hline
\end{tabular}

